\title{
Virulence-related Mycobacterium avium subsp hominissuis MAV_2928 gene is associated with vacuole remodeling in macrophages
}

\author{
Samradhni S Jha' ${ }^{1}$, Lia Danelishvili ${ }^{1 \dagger}$, Dirk Wagner ${ }^{2 \dagger}$, Jörg Maser ${ }^{3}$, Yong-jun Li $^{4}$, Ivana Moric ${ }^{3}$, Steven Vogt ${ }^{3}$,
} Yoshitaka Yamazaki ${ }^{5}$, Barry Lai ${ }^{3}$, Luiz E Bermudez ${ }^{1,6^{*}}$

\begin{abstract}
Background: Mycobacterium avium subsp hominissuis (previously Mycobacterium avium subsp avium) is an environmental organism associated with opportunistic infections in humans. Mycobacterium hominissuis infects and replicates within mononuclear phagocytes. Previous study characterized an attenuated mutant in which the PPE gene (MAV_2928) homologous to Rv1787 was inactivated. This mutant, in contrast to the wild-type bacterium, was shown both to have impaired the ability to replicate within macrophages and to have prevented phagosome/ lysosome fusion.

Results: MAV_2928 gene is primarily upregulated upon phagocytosis. The transcriptional profile of macrophages infected with the wild-type bacterium and the mutant were examined using DNA microarray, which showed that the two bacteria interact uniquely with mononuclear phagocytes. Based on the results, it was hypothesized that the phagosome environment and vacuole membrane of the wild-type bacterium might differ from the mutant. Wild-type bacterium phagosomes expressed a number of proteins different from those infected with the mutant. Proteins on the phagosomes were confirmed by fluorescence microscopy and Western blot. The environment in the phagosome of macrophages infected with the mutant differed from the environment of vacuoles with M. hominissuis wild-type in the concentration of zinc, manganese, calcium and potassium.
\end{abstract}

Conclusion: The results suggest that the MAV_2928 gene/operon might participate in the establishment of bacterial intracellular environment in macrophages.

\section{Background}

Mycobacterium avium subsp hominissuis is an environmental organism commonly found in soil and water $[1,2]$. Mycobacterium hominissuis causes disseminated disease in immunocompromised people such as in AIDS patients, and disease in patients suffering from chronic pulmonary conditions [3]. The bacterium preferentially infects tissue macrophages and blood monocytes. Once inside a macrophage, the bacterium has been shown to inhibit the acidification of the phagosome and subsequently prevent the fusion between the phagosome and lysosome [4], which are key stages of phagocytes mechanisms of killing of intracellular microorganisms

\footnotetext{
*Correspondence: luiz.bermudez@oregonstate.edu

† Contributed equally

'Department of Biomedical Sciences, College of Veterinary Medicine, Oregon
} State University, Corvallis OR 97331, USA
[5]. Similar to Mycobacterium tuberculosis [6], Salmonella [7] and Leishmania [8], M. hominissuis interferes with the endosome maturation process which precedes phagosome-lysosome fusion. The mechanisms that $M$. hominissuis uses to survive within macrophages have been an active area of research. Previous reports have shown that $M$. hominissuis has the ability to modulate the intracellular environment, remaining accessible to internalized transferrin and limiting the proteolytic activity, maintaining cathepsin D in an immature form [9]. Other studies, for example, Malik and colleagues, have suggested inhibition of calcium signaling by another pathogenic mycobacterium (M. tuberculosis) is responsible for the prevention of phagosome-lysosome fusion [10]. Li and colleagues [11], screening of $M$. hominissuis transposon mutant bank for clones with attenuated in human macrophages, identified a 2D6 
mutant in which the transposon interrupted MAV_2928 a PPE gene (52\% homologous to Rv1787 in M. tuberculosis). MAV_2928 is expressed primarily upon macrophage phagocytosis [11]. The 2D6 mutant was significantly attenuated in macrophages in comparison to the wild-type bacterium although both bacteria had comparable ability to enter the phagocytic cells. In addition, vacuoles containing the 2D6 mutant could not prevent the acidification and subsequent fusion with the lysosomes.

The PE, PPE, and PE-PGRS families of genes in mycobacteria are dispersed throughout the genomes of M. tuberculosis, Mycobacterium bovis, M. hominissuis and Mycobacterium paratuberculosis. It was previously assumed that M. hominissuis and M. paratuberculosis lack PE-PGRS family of proteins [12], but we have recently found PE-PGRS proteins in M. hominissuis ( $\mathrm{Li}$, $\mathrm{Y}$ and colleagues, in press). These families of proteins have been associated with virulence of mycobacteria $[11,13,14]$, and some of the proteins have been identified on the bacterial surface [13]. The function of the majority of PPE proteins is unknown. Recently, work with M. tuberculosis has demonstrated that PPEs are associated with the RD1 operon and participate in the secretion of ESAT- 6 and CFP-10, two proteins associated with $M$. tuberculosis virulence [15].

Early events during the infection are likely to influence the characteristics of the macrophage vacuole. MAV_2928 gene in M. hominissuis, homologue to M. tuberculosis Rv1787, is expressed upon entry in macrophages and, therefore, may participate in the establishment of the $M$. hominissuis environment within the phagocytic cell. Very little has been published on the proteins that make the bacterial vacuole. A study by Gagnon and colleagues [16] described the membrane proteins of latex bead vacuoles. Although some of the bacterial vacuole proteins have been determined, it is unknown how vacuoles recruit most of the proteins, and if bacterial vacuoles differ depending on the pathogen present within it. Previous studies have demonstrated that the intravacuolar environment is influenced by pathogens $[6,17]$. Whether this ability is related, at least in part, to changes in vacuole membrane is currently unknown. The intent of this research was to investigate whether the lack of a functional MAV_2928 would have any influence on the vacuole structure and intravacuolar environment.

\section{Results \\ Differential gene induction in U937 cells after infection with MAC 109 and 2D6 attenuated mutant by DNA microarray}

Because the MAV_2928, homologue to Rv1787, was shown to be upregulated upon initial contact between
M. avium and macrophages, we decided to examine whether and how the macrophage transcription varies upon 2D6 mutant uptake compared to the gene expression triggered by the uptake of the wild-type bacterium. Tables 1 and 2 show the genes differentially regulated when comparing the wild-type bacterium and the 2D6 mutant. The genes induced in cells infected with wild-type bacteria, but not in cells infected with the 2D6 mutant, consisted mainly of those involved in intracellular signaling, such as LCK, PKIA, DGKA, DGKD, INPP1, APBA2 and PDE1C. A few other genes were involved in the metabolic pathways, such as GPD2 (involved in glycerol-3-phosphate metabolism) and CYP4F2 (involved in leukotriene metabolism). Additional genes that showed induction were PPM1G (cell cycle arrest), HIPK3 and RORC (inhibition of apoptosis), ITK (T-cell proliferation and differentiation), GRK4 (regulation of G-protein coupled receptor protein signaling), NFKB1 (transcriptional regulator) and others. The genes with decreased expression in wild-type but upregulated in 2D6 mutant included genes involved in signal transduction (BMX, CCR3, GPR17, GABBR1, GABBR2, YWHAZ, RAB7, RAB13, IFNA1, DGKZ and DGKG), apoptosis (BLK, GZMA), bacterial uptake (ITGB1, CR1), immune response (IL10RA, TNFRSF17, MS4A1, LCP2), metabolic pathways (DDOST, PLTP), and others, such as bacterial killing (cathepsin G), negative regulators of G-protein signaling (RGS12 and RGS13), potassium channel regulator (CHP), microtubule movement (TUBB, DCTN1, CETN2 and S100A11).

\section{Macrophage gene expression analysis by quantitative real-time PCR}

To confirm the changes in macrophage gene expression level upon infection with $M$. avium or its isogenic 2D6 mutant from the DNA microarray data findings, real-time PCR analysis was used to amplify GRK4 (G-protein coupled receptor kinase 4), DGKD (Diacylglycerol kinase delta), both upregulated in the wild-type but down-regulated in the 2D6 mutant infected macrophages, and LCP2 (Lymphocyte cytosolic protein 2) down-regulated in wild-type but upregulated in the 2D6 mutant. The gene $\beta$-actin was used as a positive control, while the uninfected cells were used as a negative control. As shown in Fig. 1, the two genes GRK4 and DGKD showed significant expression upon $M$. avium infection of macrophages, in contrast to infection by the 2D6 mutant. In addition, the LCP2 gene showed significant increased expression in macrophages upon infection with 2D6 mutant, in contrast to wild-type infected macrophages. None of the three genes showed upregulation in the uninfected negative control cells. 
Table 1 Differential macrophage gene expression in M. avium 109 and 2D6 mutant

\begin{tabular}{|c|c|c|c|c|c|}
\hline Gene & $\begin{array}{l}\text { Gene Bank } \\
\text { ID }\end{array}$ & Name & Function & $\begin{array}{l}\text { Fold induction } \\
( \pm S D)\end{array}$ & $\begin{array}{l}\mathrm{p} \text { value } \\
<0.05\end{array}$ \\
\hline$\overline{\mathrm{APBA} 2}$ & AB014719 & Amyloid beta (A4) precursor protein binding & Signal transduction & $10.7 \pm 2.3$ & $\mathrm{Y}$ \\
\hline CYP4F2 & U02388 & Cytochrome P450 & $\begin{array}{l}\text { Inactivation \& degradation of } \\
\text { leukotriene B4 }\end{array}$ & $2.6 \pm 0.9$ & Y \\
\hline DGKA & AF064767 & Diacylglycerol kinase alpha & Intracellular signaling & $2.3 \pm 0.4$ & Y \\
\hline DGKD & D63479 & Diacylglycerol kinase delta & Phosphatidylinositol signaling & $6.7 \pm 1.2$ & Y \\
\hline DYNC1H1 & AB002323 & Cytosolic dyenin heavy chain & Microtubule reorganization & $17.4 \pm 3.1$ & Y \\
\hline GPD2 & NM_000408 & Glycerol-3-phosphate dehydrogenase 2 & Glycerol-3-phosphate metabolism & $3.5 \pm 0.4$ & Y \\
\hline GRK4 & NM_005307 & G-protein coupled receptor kinase 4 & $\begin{array}{l}\text { Regulation of G-protein coupled } \\
\text { receptor protein signaling }\end{array}$ & $3.5 \pm 0.6$ & Y \\
\hline HIPK3 & AF004849 & Homeodomain interacting protein kinase 3 & Inhibition of apoptosis & $2.05 \pm 0.3$ & Y \\
\hline INPP1 & NM_002194 & Inositol polyphosphate-1-phosphatase & Phosphatidylinositol signaling & $2.0 \pm 0.4$ & Y \\
\hline ITK & D13720 & IL2-inducible T-cell kinase & T-cell proliferation \& differentiation & $2.4 \pm 0.4$ & Y \\
\hline LCK & M36881 & Lymphocyte-specific protein tyrosine kinase & Intracellular signaling & $3.5 \pm 0.7$ & Y \\
\hline NFKB1 & M58603 & $\begin{array}{l}\text { Nuclear factor of kappa light polypeptide gene } \\
\text { enhancer in B-cells } 1\end{array}$ & Transcriptional regulator & $2.3 \pm 0.4$ & Y \\
\hline PDE1C & U40371 & $\begin{array}{l}\text { Calcium/calmodulin-dependant 3', 5'-cyclic } \\
\text { nucleotide phosphodiesterase } 1 C\end{array}$ & Signal transduction & $17.4 \pm 1.9$ & Y \\
\hline PKIA & S76965 & Protein kinase (cAmp-dependent) inhibitor alpha & Negative regulation of protein kinase $\mathrm{A}$ & $2.0 \pm 0.3$ & Y \\
\hline PPM1G & Y13936 & $\begin{array}{l}\text { Serine/threonine protein phosphatase PP1-gamma } 1 \\
\text { catalytic subunit }\end{array}$ & $\begin{array}{l}\text { Negative regulator of cell stress } \\
\text { response/cell cycle arrest }\end{array}$ & $3.2 \pm 0.5$ & Y \\
\hline PTPN11 & D13540 & Protein tyrosine phosphatase & Intracellular signaling, cell migration & $2.4 \pm 0.2$ & Y \\
\hline RGS3 & AF006610 & Regulator of G-protein signaling-3 & $\begin{array}{l}\text { Inhibition of G-protein mediated signal } \\
\text { transduction }\end{array}$ & $3.4 \pm 0.3$ & Y \\
\hline RORC & U16997 & RAR-related orphan receptor $C$ & $\begin{array}{l}\text { Inhibition of Fas ligand and IL2 } \\
\text { expression }\end{array}$ & $3.1 \pm 0.3$ & Y \\
\hline ROR1 & M97675 & Receptor tyrosine kinase-like orphan receptor 1 & Unknown & $4.0 \pm 0.4$ & Y \\
\hline
\end{tabular}

Complemented 2D6 mutant had similar results to the wild-type bacterium. $\mathrm{Y}=\mathrm{Yes} ; \mathrm{N}=\mathrm{No}$

\section{Mass spectrometry analysis of isolated wild-type M. avium and 2D6 phagosomes}

Several of the genes differentially regulated in macrophages upon uptake of the wild-type bacterium or the 2D6 mutants are involved in signal pathways and G-protein receptor, which suggests an early diversification when comparing both bacterial strains. It was then hypothesized that MAV_2928 may be linked to the composition of the vacuole membrane. To examine the hypothesis, we first performed proteomic analysis in purified macrophage vacuoles. As shown in Fig. 2A and 2B, purified phagosomes of cells infected with MAC 109 or 2D6 were obtained. The MS/MS results of the phagosome membranes revealed several proteins with function in bacterial uptake, antigen presentation and recognition, Rab-interacting proteins, cytoskeleton and motor proteins, proteins involved in biosynthetic pathways, transcriptional regulation, and signal transduction proteins. Several of the proteins also have function as ion channels. A number of hypothetical proteins were also identified (Table 3). Some proteins observed were unique to MAC 109 or the 2D6 vacuoles at different time points. Together, these results suggest that the phagosomes with wild-type bacterium express a number of unique proteins, different from the vacuole of the 2D6 mutant. A proteomic analysis was attempted from vacuoles of uninfected macrophages. The results obtained were variable, probably reflecting the difference of the nature of the vacuoles (data not shown).

\section{Immunofluorescence analysis}

Many proteins identified in the mass spectrometry data have not previously been described in M. avium phagosomes. To confirm the data obtained by proteomic analysis, we used fluorescence microscopy to establish the presence of some selected proteins. One of the proteins, pulmonary surfactant protein D (SP-D), was observed to be selectively expressed in the MAC 109 phagosomes at $4 \mathrm{~h}$ time point but not in the 2D6 phagosomes. The second protein, T-type $\mathrm{Ca}^{++}$channel 1 alpha, showed selective expression in 2D6 phagosomes at $24 \mathrm{~h}$ after infection and not in the MAC 109 phagosomes.

SP-D is a carbohydrate binding glycoprotein and has been shown to be involved in ligand binding and immune cell recognition [18]. To confirm the expression of SP-D on MAC 109 vacuoles at $4 \mathrm{~h}$ time point, cells were infected in parallel with fluorescein-labeled bacteria (MAC 109 and 2D6) for $4 \mathrm{~h}$. The SP-D 
Table 2 Macrophage genes with decreased expression in M. avium 109 but increased in 2D6 mutant 4 h post infection

\begin{tabular}{|c|c|c|c|c|c|}
\hline Gene & $\begin{array}{l}\text { Gene Bank } \\
\text { ID }\end{array}$ & Name & Function & $\begin{array}{l}\text { Fold induction } \\
( \pm \text { SD) }\end{array}$ & $\begin{array}{c}\mathrm{p} \text { value } \\
<0.05\end{array}$ \\
\hline AMBP & X04494 & Alpha-1-microglobulin & $\begin{array}{l}\text { Negative regulation of immune response/ } \\
\text { Protease inhibitor }\end{array}$ & $4.2 \pm 0.7$ & $Y$ \\
\hline BLK & BC004473 & B-lymphoid tyrosine kinase & Apoptosis & $3.3 \pm 0.3$ & Y \\
\hline $\mathrm{BMX}$ & AF045459 & BMX non-receptor tyrosine kinase & Intracellular signaling & $18.6 \pm 4.1$ & Y \\
\hline CCR3 & AF247361 & Chemokine receptor 3 & Signal transduction & $4.1 \pm 0.6$ & Y \\
\hline CD53 & BC040693 & CD53 molecule & Growth regulation & $4.1 \pm 0.3$ & Y \\
\hline CETN2 & X72964 & Centrin, EF-hand protein 2 & Microtubule organization center & $6.3 \pm 0.9$ & Y \\
\hline $\mathrm{CHP}$ & NP_009167 & Calcium binding protein P22 & $\begin{array}{l}\text { Potassium channel regulator/Signal } \\
\text { transduction }\end{array}$ & $20.8 \pm 3.5$ & Y \\
\hline CR1 & Y00816 & Complement receptor 1 & Bacterial uptake & $4.3 \pm 0.4$ & Y \\
\hline CTSG & NM_001911 & Cathepsin G & Bacterial killing & $2.9 \pm 0.2$ & Y \\
\hline DCTN1 & NM_004082 & Dynactin 1 & Lysosome and endosome movement & $35.8 \pm 8.0$ & Y \\
\hline DDOST & D29643 & $\begin{array}{l}\text { Dolichyl-diphosphooligosaccharide-protein } \\
\text { glycosyltransferase }\end{array}$ & N-linked glycosylation & $3.3 \pm 0.3$ & Y \\
\hline DGKG & AF020945 & Diacylglycerol kinase gamma & Intracellular signaling & $5.3 \pm 0.6$ & Y \\
\hline DGKZ & U51477 & Diacylglycerol kinase zeta & Intracellular signaling & $48.1 \pm 6.1$ & Y \\
\hline EMILIN2 & AF270513 & Elastin microfibril interfacer 2 & Cell adhesion & $14.7 \pm 3.7$ & Y \\
\hline FOXC2 & Y08223 & Forkhead box C2 & Transcription factor & $5.9 \pm 1.5$ & Y \\
\hline GABBR1 & Y11044 & GABA receptor 1 & Signal transduction & $6.1 \pm 2.0$ & Y \\
\hline GABBR2 & AF069755 & GABA receptor 2 & Signal transduction & $2.8 \pm 0.4$ & Y \\
\hline GPR17 & NM_005291 & G-protein coupled receptor 17 & Signal transduction & $83.2 \pm 12.5$ & Y \\
\hline GZMA & NM_006144 & Granzyme A & Apoptosis & $2.1 \pm 0.6$ & Y \\
\hline IFNA1 & NM_024013 & Interferon alpha 1 & Intracellular signaling & $2.6 \pm 1.0$ & Y \\
\hline IL10RA & U00672 & Interleukin 10 receptor alpha & $\begin{array}{l}\text { Inhibition of proinflammatory cytokine } \\
\text { synthesis }\end{array}$ & $2.3 \pm 0.2$ & Y \\
\hline ITGB1 & BC020057 & Fibronectin receptor & Bacterial uptake & $4.6 \pm 0.7$ & Y \\
\hline LCP2 & NM_005565 & Lymphocyte cytosolic protein 2 & Immune response & $37.5 \pm 9.2$ & Y \\
\hline MCAM & X68264 & Melanoma cell adhesion molecule & Cell adhesion & $4.7 \pm 0.2$ & Y \\
\hline MS4A1 & M27394 & Membrane-spanning 4-dmains & Immune response & $9.6 \pm 0.9$ & Y \\
\hline PBX2 & NM_002586 & Pre-B-cell leukemia transcription factor 2 & Transcriptional activator & $3.0 \pm 0.3$ & Y \\
\hline PLTP & NM_006227 & Phospholipid transfer protein & Lipid metabolism & $3.6 \pm 0.5$ & Y \\
\hline RAB7 & X93499 & RAS related GTP binding protein & Vesicular transport regulation & $3.4 \pm 0.4$ & Y \\
\hline RAB13 & X75593 & RAS related GTP binding protein & Small GTPase mediated signal transduction & $7.5 \pm 1.1$ & Y \\
\hline RGS12 & AF035152 & Regulator of G-protein signaling 12 & Negative regulation of G-protein signaling & $3.0 \pm 0.3$ & Y \\
\hline RGS13 & AF030107 & Regulator of G-protein signaling 13 & Negative regulation of G-protein signaling & $2.6 \pm 0.4$ & Y \\
\hline S100A11 & NM_005620 & Calgizzarin & Motility, invasion \& tubulin polymerization & $9.6 \pm 0.8$ & Y \\
\hline TNFRSF17 & Z29574 & TNF receptor & Immune response & $2.6 \pm 0.3$ & Y \\
\hline TUBB & AB062393 & Tubulin beta & Microtubule based movement & $4.0 \pm 0.3$ & Y \\
\hline YWHAZ & NM_003406 & Tyrosine 3-monooxygenase & Signal transduction & $4.3 \pm 0.5$ & Y \\
\hline
\end{tabular}

Complemented 2D6 mutant had similar results to the wild-type bacterium. $\mathrm{Y}=\mathrm{Yes} ; \mathrm{N}=\mathrm{No}$

protein was observed to be present in nearly all on the MAC 109 vacuoles (Fig. 3, A-C). In vacuoles with the 2D6-mutant, as well as in uninfected, macrophage, no SP-D was co-localized with M. avium (Fig. 3, D-F \& Fig. 3, G-H, respectively). Quantification is shown in Fig. 4. This finding confirmed our data that SP-D is expressed in MAC 109 phagosomes but not in 2D6 mutant phagosomes at $4 \mathrm{~h}$ time point. The protein was also seen in the membrane of infected macrophages.
To investigate whether the complemented $M$. avium 2D6 mutant phagosomes showed similar protein expression as that of wild-type, we infected the cells with 2D6 complemented bacteria [11] for $4 \mathrm{~h}$, with MAC 109 as a positive control. The vacuoles containing the complemented M. avium 2D6 mutant showed expression of SP-D protein (Fig. 5A-5C) similarly to vacuoles containing the wild-type bacterium (Fig. 5D and 5E), though the percentage of infected cells showing the protein expression was $15 \%$ less than in macrophages infected 


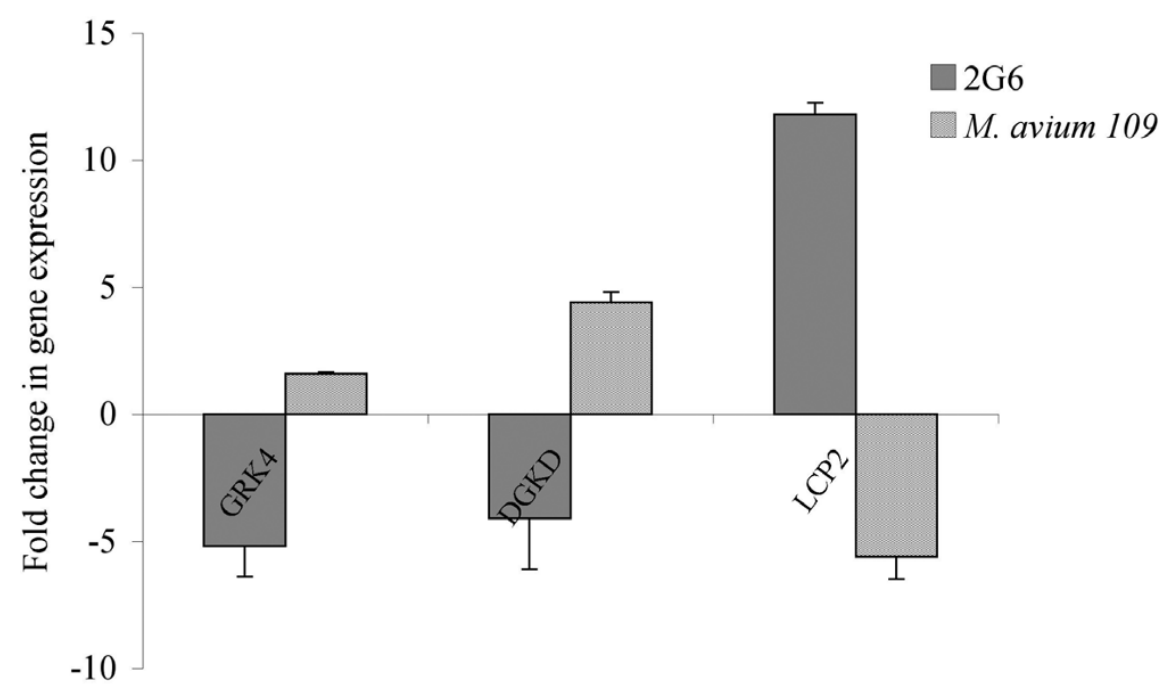

Macrophage genes

Figure 1 Upregulation of U937 macrophage genes upon infection with M. avium or 2D6 mutant at $4 \mathrm{~h}$, as determined by real-time PCR. U937 were infected with MAC 109 or MAC 2D6. Four hours later, macrophage RNA was purified and used for real-time PCR to measure the expression of GRK4, DGKD and LCP2. The data represent the average of three independent experiments \pm SD. A p $<0.05$ for the three genes compared with the regulation in the other strain.

with the wild-type bacterium. Quantification of expression is shown in Fig. 4.

$\mathrm{T}$-type $\mathrm{Ca}^{++}$channel is an integral membrane protein, which controls the rapid entry of $\mathrm{Ca}^{++}$into excitable cells, and is activated by CaM-Kinase II (Swiss-Prot database). To verify our initial observation by MS/MS, we carried out parallel infection assays with fluoresceinlabeled 2D6 and MAC 109 bacteria for 24 h. As shown in Fig. $6 \mathrm{~A}$ and $6 \mathrm{~B}$, the majority of the cells infected with 2D6 mutant showed T-type $\mathrm{Ca}^{++}$channel protein staining; whereas, those infected with the wild-type MAC 109 and uninfected control U937 cells failed to express the protein (Fig. 6C and 6D, Fig. 6E and 6F, respectively). The observation was in agreement with the proteomic data showing that $\mathrm{T}$-type $\mathrm{Ca}^{++}$channel is expressed in mononuclear phagocytes infected with 2D6 attenuated mutant, but not when infected with MAC 109.

To determine whether the phagosomes of macrophages infected with the complemented M. avium 2D6 mutant phagosomes failed to express the $\mathrm{T}$-type $\mathrm{Ca}^{++}$ channel, mononuclear cells infected with complemented M. avium 2D6 bacteria and 2D6-attenuated mutant were evaluated. As shown in Fig. 7A and 7B, vacuoles with the complemented bacteria, in contrast to the 2D6 mutant (Fig. 7C and 7D), did not express T-type $\mathrm{Ca}^{++}$ channel protein. Quantification of the T-type $\mathrm{Ca}^{++}$ channel protein in macrophages infected with MAC 109, the 2D6 mutant and complemented 2D6 strain are shown in Fig. 8.
The expression of EEA-1, CREB-1, and TNFRI were also quantified by immunofluorescence microscopy, as shown in Fig. 9-Fig. 11. Expression of EEA-1, CREB-1 and TNFRI proteins was selectively observed after macrophage infection with 2D6 bacteria but not in the vacuoles of macrophages infected with the wild-type bacterium. Western blot analysis showed that EEA-1 and CREB-1 proteins were only expressed in vacuoles occupied by the 2D6 mutant and not the wild-type bacteria. MARCO, a protein shown by the mass spectrometry to be expressed differently in macrophages infected by the mutant and wild-type bacterium, was present in the vacuole membrane of the wild-type bacterium at 30 min but not in 2D6 mutant vacuole. The expression decreased significantly in the vacuole of the wild-type $M$. avium at $24 \mathrm{~h}$ but increased significantly in the vacuoles of 2D6 mutants (Fig. 12).

\section{X-ray microscopy measures of intravacuolar concentrations of elements}

Because the changes in the vacuole membrane might translate into changes in the vacuole environment, we carried out hard x-ray microscopy to evaluate the level of single elements within the bacterial vacuole. We observed that, at $1 \mathrm{~h}$ after infection, the concentration of $\mathrm{Mn}^{++}$and $\mathrm{Zn}^{++}$were significantly higher in vacuoles occupied by the 2D6 mutant than in vacuoles of the wild-type bacterium. At $24 \mathrm{~h}$, the concentration of $\mathrm{Mn}^{++}$remained similar in vacuoles with the 2D6 mutant but decreased in 

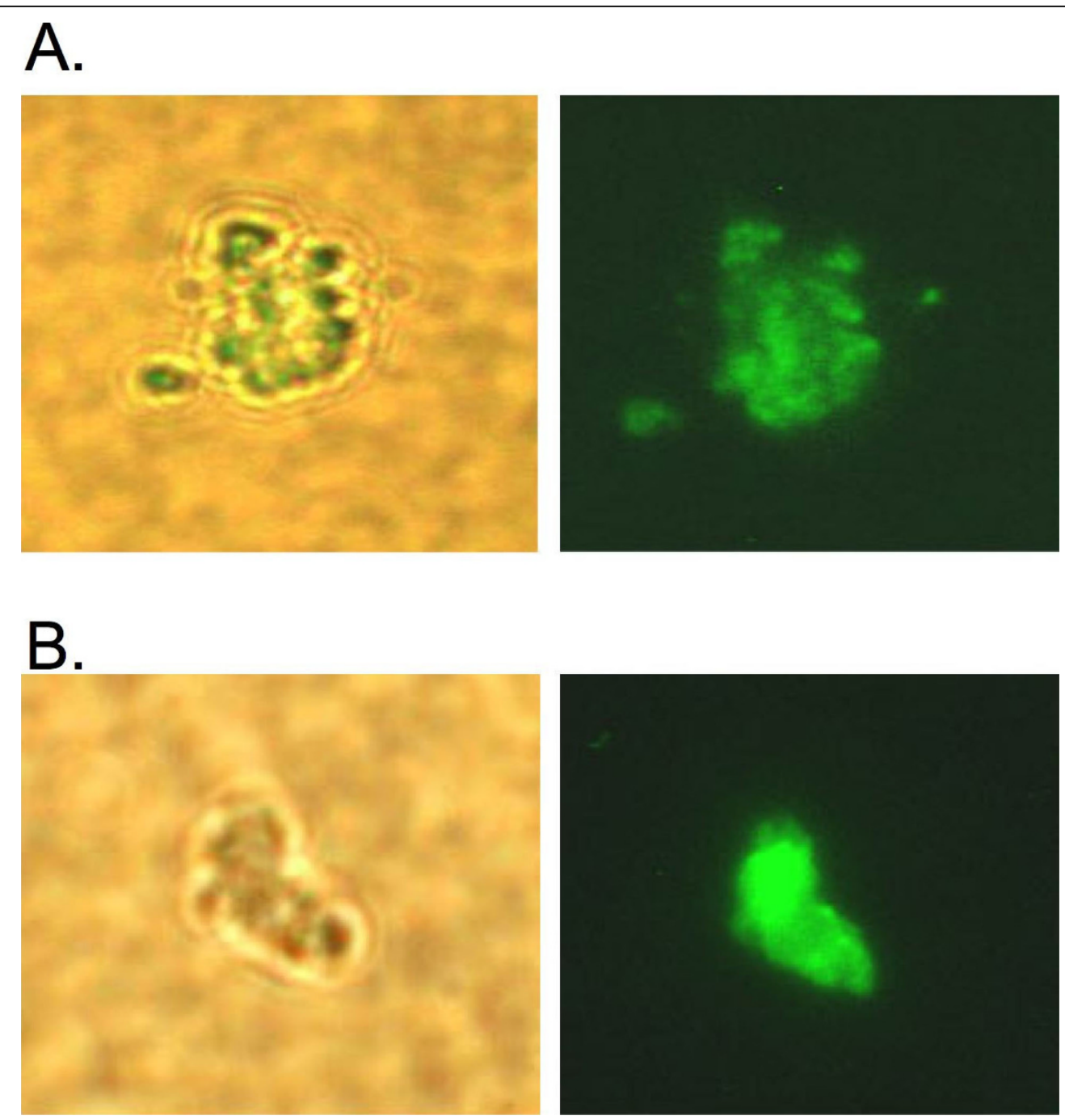

Figure 2 Fluorescent microscopy images of isolated phagosomes showing phase contrast and fluorescein labeled images of: (A) M. avium and (B) 2D6 mutant. M. avium vacuoles were purified according to method described in Materials and Methods. After centrifugation, purified phagosomes were analyzed under microscopy for purity.

vacuoles of the wild-type organism. The concentrations of $\mathrm{Ca}^{++}$and $\mathrm{K}^{+}$also decreased over time in 2D6 mutant vacuoles, becoming significantly different from the wildtype bacterium (Table 4). The concentration of $\mathrm{Zn}^{++}$, while still significantly different between the wild-type bacterium and the 2D6 mutant, also decreased over time (Table 4). The concentration of iron in the vacuole of 2D6 mutant did not differ from the concentration in vacuoles with the wild-type bacterium.

\section{Discussion}

$M$. avium, like $M$. tuberculosis, primarily infects the host mononuclear phagocytes. Targeting mononuclear phagocytes and being able to survive within the presence of efficient mechanisms of macrophage subversion, evolved by virulent.
In M. tuberculosis, PE-PGRS and PPE are two families of glycine-rich protein which constitute approximately $10 \%$ of the $M$. tuberculosis genome. Recent reports have suggested that these two gene families might be involved in antigen variation, eukaryotic cell binding, survival within macrophages and persistence in granulomas $[19,20]$. Richardson and colleagues (2001) showed that a PPE protein (Rv1917) is expressed on the bacterial surface. Using signature-tagged mutagenesis, Camacho and colleagues identified a PPE gene (Rv3018c) associated with $M$. tuberculosis virulence in vivo [21]. In addition, Ramakrishnan and colleagues observed that inactivation of PE-PGRS gene in Mycobacterium marinum resulted in attenuation of bacterial virulence in macrophages [19]. In a recent report, Li and colleagues [11] demonstrated that an $M$. avium strain lacking a functional PPE 
Table 3 List of phagosomal proteins identified by MS/MS post-infection with MAC 109 or 2D6 at different time points

\begin{tabular}{|c|c|c|c|c|c|c|c|}
\hline \multirow{2}{*}{$\begin{array}{l}\text { Protein } \\
\text { Bacterial Uptake }\end{array}$} & \multirow{2}{*}{$\begin{array}{l}\text { Accession } \\
\text { number }\end{array}$} & \multicolumn{3}{|c|}{$\begin{array}{c}\text { MAC } 109 \\
\text { (h) }\end{array}$} & \multicolumn{3}{|c|}{$\begin{array}{l}\text { 2D6 mutant } \\
\text { (h) }\end{array}$} \\
\hline & & 0.5 & 4 & 24 & 0.5 & 4 & 24 \\
\hline Complement clq tumor necrosis factor related protein 5 & Q9BXJ0 & $x$ & $x$ & & & $\mathrm{x}$ & \\
\hline Complement receptor 2 & P20023 & & & $x$ & & & \\
\hline Macrophage receptor MARCO & Q9UEW3 & $x$ & $x$ & & & $x$ & \\
\hline Pulmonary surfactant protein $\mathrm{D}$ & P35247 & & $x$ & & & & \\
\hline Scavenger receptor with $C$ type Lectin type 1 & Q9BYH7 & $x$ & & & & & \\
\hline TNFRSF1A-associated via death domain/TRADD & Q15628 & & & & $x$ & & \\
\hline Tumor necrosis factor receptor member 1A/TNFRSF1A & 1NCFA & & & & & & $x$ \\
\hline
\end{tabular}

\section{Antigen Presentation \& Recognition}

Integrin alpha 1

P56199

Integrin alpha IIb

P08514

MHC class I

Q95ID4

MHC class $\|$

154427

\section{Rab Interacting}

EEA1

Peroxin 5-related protein

Rabaptin 5

Q15276

\section{Cytoskeletal Proteins \& Motors}

Alpha actin

P62736

Ankyrin 1

Q658J3

Beta actin

Q96B34

E-MAP-115

Q14244

Keratin, type II cytoskeletal I

P04264

Kinesin/KIF3

014782

Kinesin family member $26 \mathrm{~A}$

Q8TAZ7

L-plastin

P13796

Myosin heavy chain non-muscle type A

P35579

Myosin $X$ with ATPase activity

Q9HD67

$\mathrm{RHOC}$

P08134

TCP-1 zeta

P40227

Tubulin alpha

Q71U36

Q13748

Tubulin alpha 2

Q71U36

Tubulin alpha 3

P07437

Proteins in Biosynthetic Pathways

ABC transporter 2

Q9BZC7

ADP-ATP translocase

P05141

Aldoketo-reductase 3

Q9UFE1

ALG12

ATP synthase

Q9BV10

P06576

Fatty acid synthase

P49327

Fatty acid transporter member 1

Q6PCB7

P04406

GAPDH

Q92643

Phosphatidyl inositol glycan class T

P12268

IMP dehydrogenase

T17231

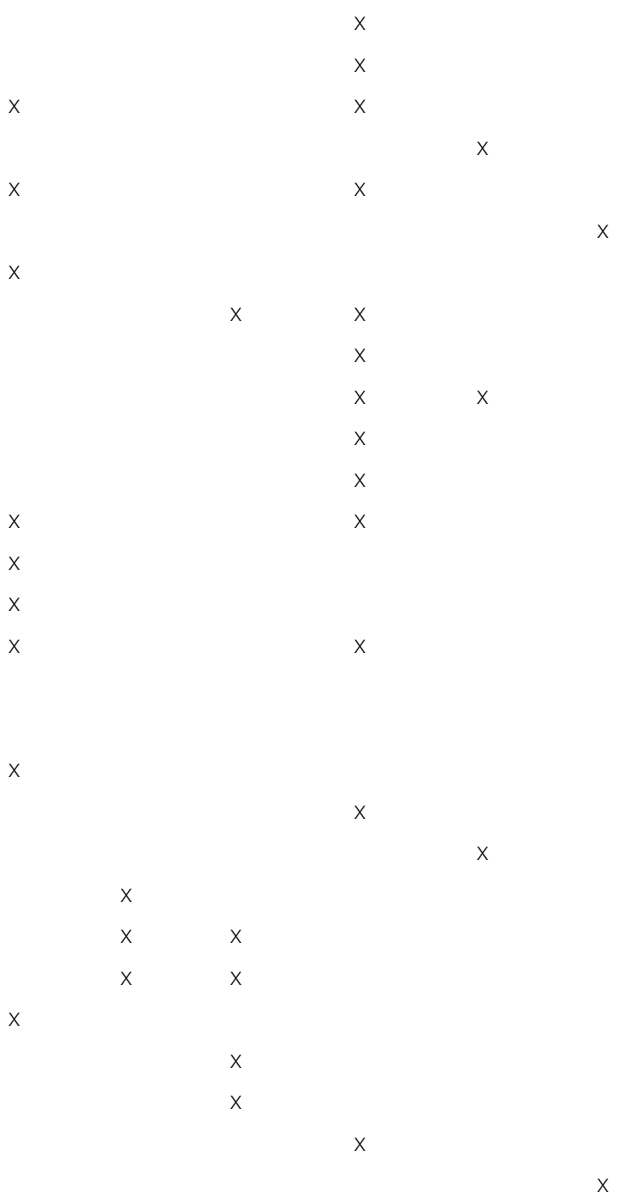


Table 3: List of phagosomal proteins identified by MS/MS post-infection with MAC 109 or 2D6 at different time points (Continued)

Mitochondrial dicarboxylate carrier

Q9UBX3

Q15758

Neutral amino acid transporter

NUAK family, SNF1-like kinase 1

PI4KII

Pyruvate kinase

Ribophorin II

Trehalose precursor

\section{Transcriptional Regulators}

Lysine-specific histone demethylase 1

O60285

Q9BTU6

PS00110

Q5JYR7

O43280

CRSP complex subunit 2

CREB binding protein

DEAH box polypeptide 9

IFI 16

Msx2-interacting protein

p-100 co-activator/SND1

p-300/CBP associated factor

Zinc finger \& BTB domain containing protein 4

Zinc finger protein 588

Zinc finger protein 43

$60 \mathrm{~S}$ acidic ribosomal protein P2

$60 \mathrm{~S}$ ribosomal protein L6

$60 \mathrm{~S}$ ribosomal protein L9

$60 \mathrm{~S}$ ribosomal protein L14

\section{Proteins Interacting with Signal Proteins}

cAMP-specific 3',5'-cyclic phospho-diesterase

Calcium \& lipid binding protein/NLF2

Chondroitin sulfate synthase 3

CXC3C membrane-associated chemokine

Doublecortin \& CaM kinase like-3

Dystrobrevin alpha

Golgin subfamily A member 5

Microtubule associated-Ser/The kinase 3

Protein kinase A anchoring protein 9

Protein kinase $\mathrm{N}$

Serine/theonine kinase 16

TER ATPase

\section{Ion Channels}

Amiloride-sensitive cation channel

Voltage dependent-N-type calcium channel alpha 1B subunit

Voltage dependent-T-type calcium channel alpha 1 l subunit

\section{Other Proteins}

AFG3 like protein 2

APBB1

Astrotactin 2

Apoptotic chromatin-condensation inducer in the nucleus

Clathrin heavy chain 1

Ephrin B3
Q00975

O60341

O60244

Q75MY6

Q08211

Q16666

Q96T58

Q7KZF4

Q92831

Q9P1Z0

Q9UIII5

P17038

P05387

Q02878

P32969

P50914

Q08493

388125

Q86Y52

P78423

Q9C098

Q9Y4J8

Q8TBA6

O60307

Q99996

Q8NF44

Q5U0F8

P55072

Q9P0X4

Q9Y4W6

000213

O75129

Q9UKV3

Q00610

Q15768 $x$

$x$

$x$

X

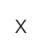

$x$

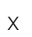

$x$

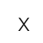

X

X

$x$ $x$

$x$

$x$

$x$

x

X

$x$

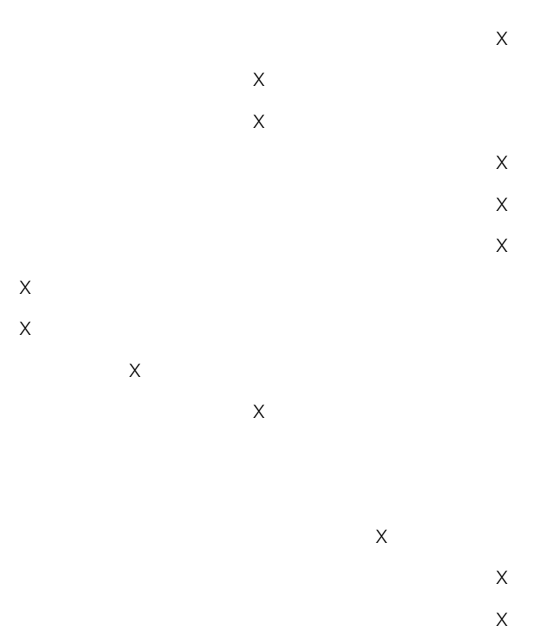


Table 3: List of phagosomal proteins identified by MS/MS post-infection with MAC 109 or 2D6 at different time points (Continued)

\begin{tabular}{|c|c|c|c|c|c|c|c|}
\hline $48 \mathrm{kda}$ histamine receptor subunit peptide 4 & AAB34251 & & & $x$ & & & \\
\hline HSP 60 & P10809 & & & & $x$ & & \\
\hline HSP 90 & P07900 & & & & $x$ & & \\
\hline Importin alpha 2 & P52292 & & & & $x$ & & \\
\hline Interferon regulatory factor 6 & 014896 & & & & & & $x$ \\
\hline LRCH4/Ligand binding receptor & O75427 & & & & & & $x$ \\
\hline NADPH oxidase activator 1 & Q2TAM1 & & & & & & $x$ \\
\hline Protein disulfide-isomerase A6 & P07237 & $x$ & & & $x$ & & \\
\hline p-53-associated parkin-like cytoplasmic protein/PARC & Q8IWT3 & & & & & $x$ & \\
\hline Serine protease inhibitor & Q9NQ38 & & $x$ & & & & \\
\hline Vitrin & Q6UX17 & & & & & & $x$ \\
\hline 14-3-3 protein/Tyrosine 3-monoxygenase & P62258 & & & & $x$ & & \\
\hline \multicolumn{8}{|l|}{ Proteins with Unknown Function } \\
\hline Hypothetical protein DKFZp434A128 & T34567 & & & & & & $x$ \\
\hline Hypothetical protein LOC136288 & Q8NEG2 & & & & & & $x$ \\
\hline Hypothetical protein KIA1783 & Q96JP2 & & & & & & $x$ \\
\hline Hypothetical protein KIAA1783 & Q96JP2 & & & & & & $x$ \\
\hline Hypothetical protein FLJ32795 & Q96M63 & & & & & $x$ & \\
\hline Hypothetical protein FLJ42875 & Q8N6L5 & & & & & $x$ & \\
\hline Hypothetical protein FLJ45491 & Q6ZSI8 & & & $x$ & & & \\
\hline Hypothetical protein DKFZp434G131 & Q9HOH4 & & $x$ & & & & \\
\hline Hypothetical protein FLJ46534 & Q6ZR97 & $x$ & & & & & \\
\hline Hypothetical protein FLJ00361 & Q8NF40 & $x$ & & & & & \\
\hline
\end{tabular}

Complemented 2D6 mutant had similar results to the wild-type bacterium. $\mathrm{Y}=\mathrm{Yes} ; \mathrm{N}=\mathrm{No}$

protein, MAV_2928 (homologue to Rv1787), is attenuated in vivo and fails to inhibit both acidification of the vacuole, as well as phagosome-lysosome fusion. Mycobacterium avium MAV_2928 transposon mutant had comparable ability to enter the mononuclear phagocytes as the wild-type bacterium. The expression of MAV_2928 was noted following uptake of the wild-type bacterium by macrophages but not in culture media, suggesting a possible participation in the early events of the intracellular stage and possibly in phagosome formation [11].

The gene MAV_2928 is part of an M. avium chromosomal region with five PPE and PE genes, adjacent to the region homologous to the RD5 region in $M$. tuberculosis. The organization of this region suggests the existence of three promoters, one upstream of MAV_2928 inactivated in the 2D6 mutant, one between the second, and the third genes and another between the fourth and fifth genes in the downstream region [11]. This specific region is also upstream of a region homologous to the RD1 region of $M$. tuberculosis. A PPE gene adjacent to the RD1 region in M. tuberculosis has been suggested to be associated with the transport of proteins [15]. Because MAV_2928 is co-transcribed with MAV_2929, it is possible that some of the findings are due to the downstream gene. Complementation of the 2D6 mutant, however, has shown that most of the function lost with the inactivation of MAV_2928 is recovered [11]. Interestingly, MAV_2925 has a high degree of homology with MAV_2928, but, based on the phenotype obtained with the inactivation of MAV_2928, we assume that the genes probably have unique functions.

Usually, upon bacterial uptake, a macrophage undergoes a series of events specifically designed to eliminate the engulfed microorganism. These include induction of reactive oxygen and nitrogen intermediates, gradual acidification of the phagosome, phagosome-lysosome fusion which loads the resulting compartment with acidic proteolytic enzymes, and antigen processing and presentation. The resulting lethal environment effectively kills the majority of the ingested bacteria. Pathogenic mycobacterial phagosomes, in contrast, show incomplete luminal acidification and absence of mature lysosomal hydrolases [22]. Malik et al. [10,23,24] suggested that $M$. tuberculosis manipulation of calcium is in part responsible for the phagosome maturation arrest. The pathogenic mycobacterial phagosome has been shown to alter the trafficking of the plasma membrane markers, including MHC molecules [25], EEA-1 and 


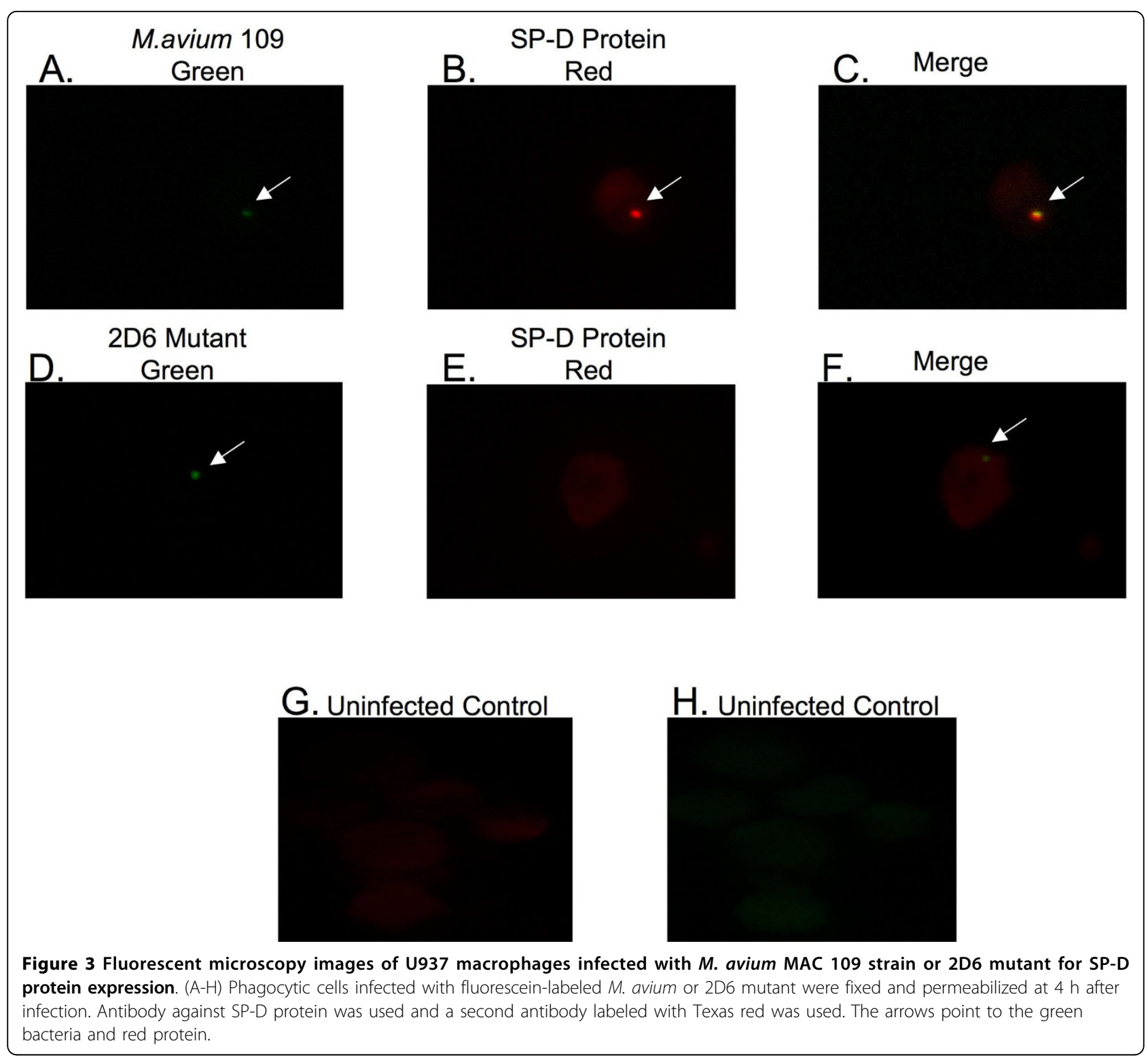

LAMP-1 [6]. M. tuberculosis-related blocking of phagosome maturation in macrophages appears to take place between the maturation stages controlled by early endocytic marker Rab5 and late endocytic marker Rab7 [6]. The published data indicate that virulent mycobacterial phagosomes are selective in their fusion with various cytoplasmic organelles and do not mature into a phagosome-lysosome. Currently unknown is whether this ability to impact the docking and incorporation of proteins in the phagosome membrane is due completely, or partially, to the proteins that form the phagosome membrane is currently unknown. It is a plausible possibility. This interpretation could explain the differences between the vacuole proteomic between both bacterial strains.
Based on the results obtained in the macrophage transcriptome following infecting with $M$. avium or the 2D6 clone, it is clear that the mutant stimulates membranebased signals and receptors that are bypassed by the wild-type bacterium.

Mass spectrometry analysis of the phagosomal proteins of 2D6 mutant and the wild-type bacterium yielded several differences in the protein expression in the vacuole membrane. For example, expression of EEA-1 and Rab5 effectors was seen on 2D6 phagosomes but not on the wild-type phagosomes, which is in agreement with the observation reported by Fratti et al. and Via et al. $[6,26]$. The upregulation of Rab7 on the 2D6-infected macrophages indicates that the 2D6 mutant expresses late endosome markers and undergoes phagolysosome fusion [11]. 


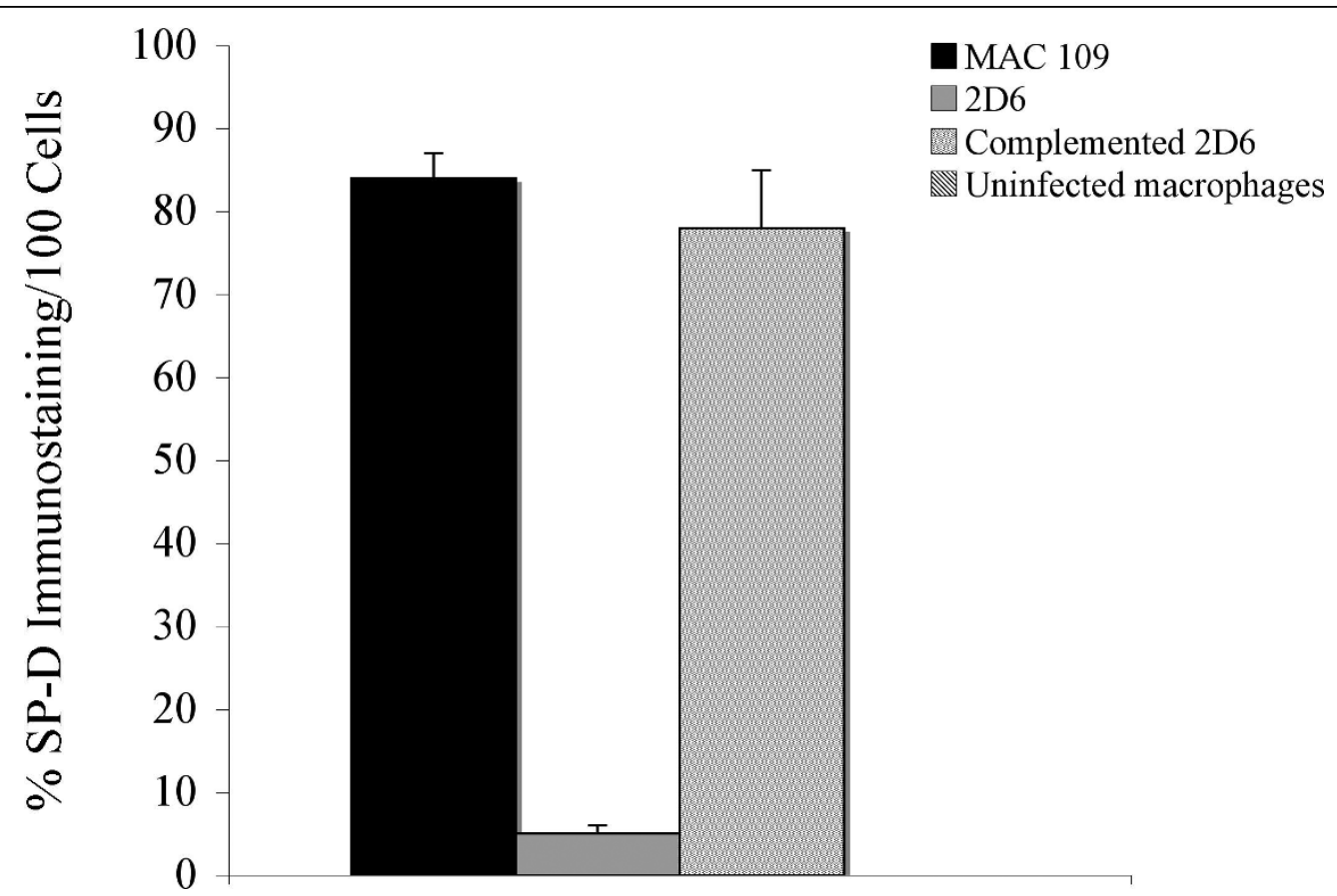

Figure 4 Quantification of the SP $=$ D protein expression assay in 100 U937 cells. The numbers represent the mean \pm SD of three experiments.

A relatively large body of published data suggests the role of complement receptors CR1, CR3 and CR4 [27] and a mannose receptor [27] in the uptake of M. tuberculosis by macrophages. It has been shown that CR3 is one of the main receptors involved in phagocytosis of $M$. avium by macrophages and monocytes $[28,29]$. The CR2 was identified among various receptors on $M$. avium phagosomes. Studies have suggested an important role of CR1/2, CR3 and CR4 in host defense against Streptococcus pneumoniae infections [30]. Functional studies have demonstrated that CR2 mediates tyrosine phosphorylation of $95 \mathrm{kDa}$ nucleolin and its interaction with phosphatidylinositol 3 kinase [31].

Surfactant-associated proteins A and D (SP-D) are pulmonary collectins that bind to bacterial, fungal and viral pathogens and have multiple classes of receptors on both pneumocytes and macrophages [32]. In addition, they act as chemoattractant to phagocytes. Surfactant proteins A and D (SP-A and -D) participate in the innate response to inhaled microorganisms and organic antigens and contribute to immune and inflammatory regulation within the lung [33]. Ferguson and colleagues showed that SP-D binds to M. tuberculosis, resulting in decreased uptake and inhibition of bacterial growth [34]. The presence of SP-D in phagosomes MAC 109 suggests a host attempt to eliminate the pathogen. Surfactant protein A (SP-A) expressed on M. tuberculosis vacuoles has been shown to be involved in enhancing the uptake of bacteria by macrophages [35-37].

The lack of MHC class II molecule expression in $M$. avium phagosomes, and its presence in the attenuated 2D6 mutant phagosomes in our data, is in agreement with the above findings that MHC class II molecules are down-regulated upon mycobacterial infection [38-40]. The MHC class I molecules are involved in presentation of the antigens located in the cytoplasm. The fact that MHC class I molecules were found on 2D6 mutant phagosomes, at $24 \mathrm{~h}$ time point, may reflect altered trafficking by the bacteria. In addition, MHC class I expression at early time points on the phagosome would suggest that the protein being present on the cell surface, during phagocytosis, would have been ingested upon during vacuole formation. The presence of MHC class I molecules on the 2D6 phagosomes could also be due to the fact that mycobacterial antigens are processed by MHC class I [41]. The MHC class I has been reported to be present on latex bead phagosomes [42].

Several proteins not previously shown to be associated with the mycobacterial phagosomes were identified in the phagosomal preparations. Because we could not completely rule out the possibility of contamination of the phagosome preparations with other organelles, which indeed is a limiting factor of most subcellular fractionation techniques, we confirmed the findings by 


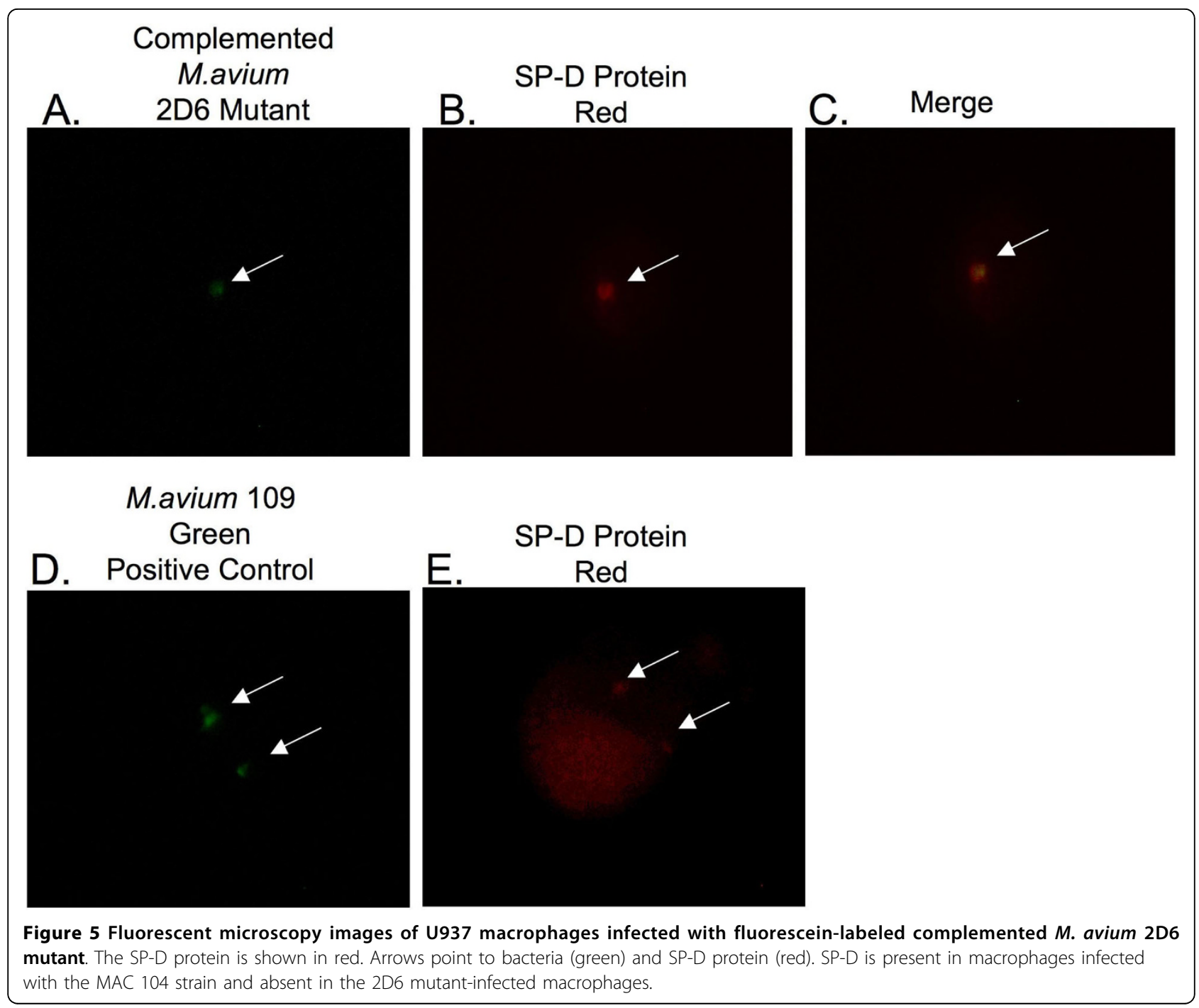

identifying proteins by fluorescence microscopy and Western blot. Recent studies on Legionella and Brucella have shown that these organisms reside in compartments displaying features of endoplasmic reticulum (ER) [43]. In addition, there is evidence of recruitment of endoplasmic reticulum (ER) to nascent phagosomes containing inert particles or Leishmania and having a major contribution to the phagosomal membrane [16]. This explains how antigens of vacuolar pathogens are presented to T lymphocytes via MHC class I machinery located on ER. Considering this information, it would be plausible to find ER particles on mycobacterial phagosomes. Some of the mitochondrial proteins, such as ATP synthase and HSP60 found in our preparations, have also been shown to be present in latex bead containing phagosomes [42].

A recent report on the elemental analysis of $M$. avium phagosomes in Balb/c mouse macrophages revealed high concentrations of potassium and chlorine at $24 \mathrm{~h}$ time point and correlated it to the microbiocidal killing similar to that observed in neutrophils [44]. The increase in expression of CHP (potassium channel regulator) in the 2D6-infected macrophages, added to the finding that $\mathrm{K}-\mathrm{Cl}$ co-transporter is also increased (proteomic results) on the 2D6 mutant phagosomes at $24 \mathrm{~h}$ time point, could support, at least in part, the above published report, since the 2D6 mutant is unable to survive within the macrophages [11]. Therefore, there is a possibility that $\mathrm{K}-\mathrm{Cl}$ transporter and $\mathrm{CHP}$ could be involved in the augmentation of the potassium and chlorine concentrations in the phagosome, leading to mutant killing, but this will have to be tested in future work. Because of the observed difference in vacuole membrane between the two tested bacterial strains, it was hypothesized that the difference might impact the content of the metals in the vacuole environment. 

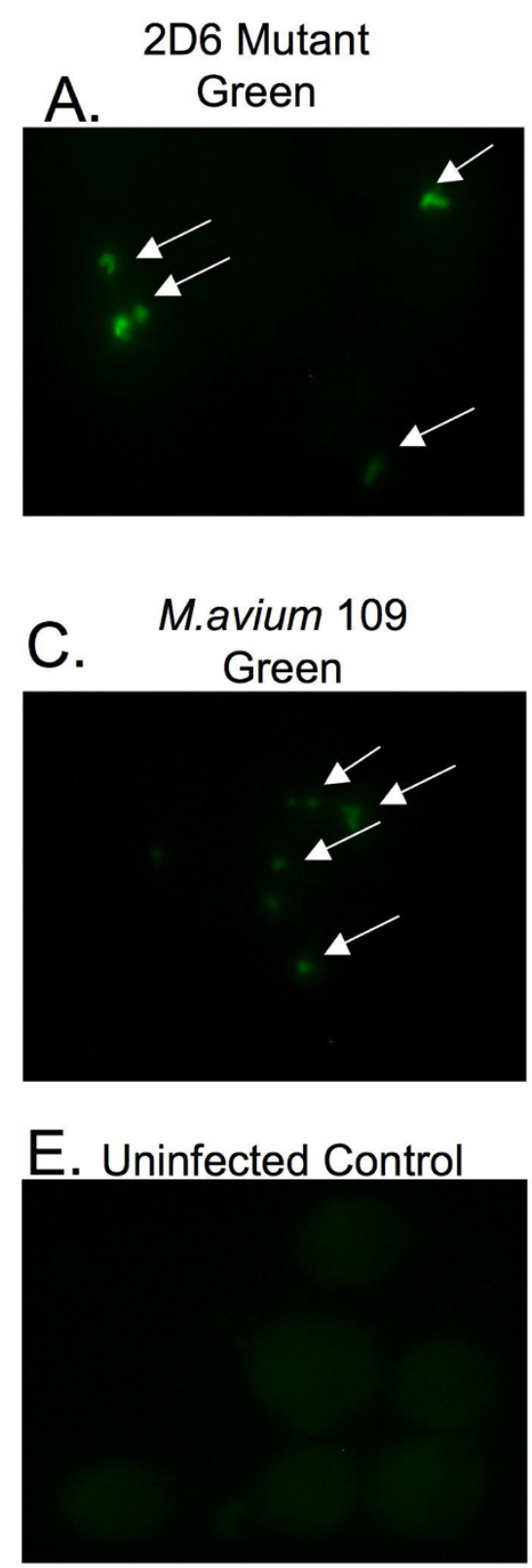

Figure 6 Fluorescent microscopy images of U937 macrophages infected with fluorescein-labeled M. avium MAC 109 strain or 2D6 mutant. Macrophages were fixed and permeabilized $24 \mathrm{~h}$ after infection. Antibody anti-T-type $\mathrm{Ca}^{++}$channel protein was used for $1 \mathrm{~h}$, washed, and second antibody labeled with Texas red was applied for an additional hour. The arrows point to the green bacteria and red protein (A-F).

Measurement of the intravacuolar concentration of single elements demonstrates that the 2D6 mutant's vacuole is depleted of several important elements at $24 \mathrm{~h}$ after infection. The decrease in the intravacuolar concentrations of $\mathrm{Ca}^{++}$and $\mathrm{Zn}^{++}$suggests that the wildtype bacteria are capable of retaining the elements, but the PPE mutant is not, probably indicating that the mutant cannot suppress the transport mechanisms or cannot continue to induce uptake of the metals.
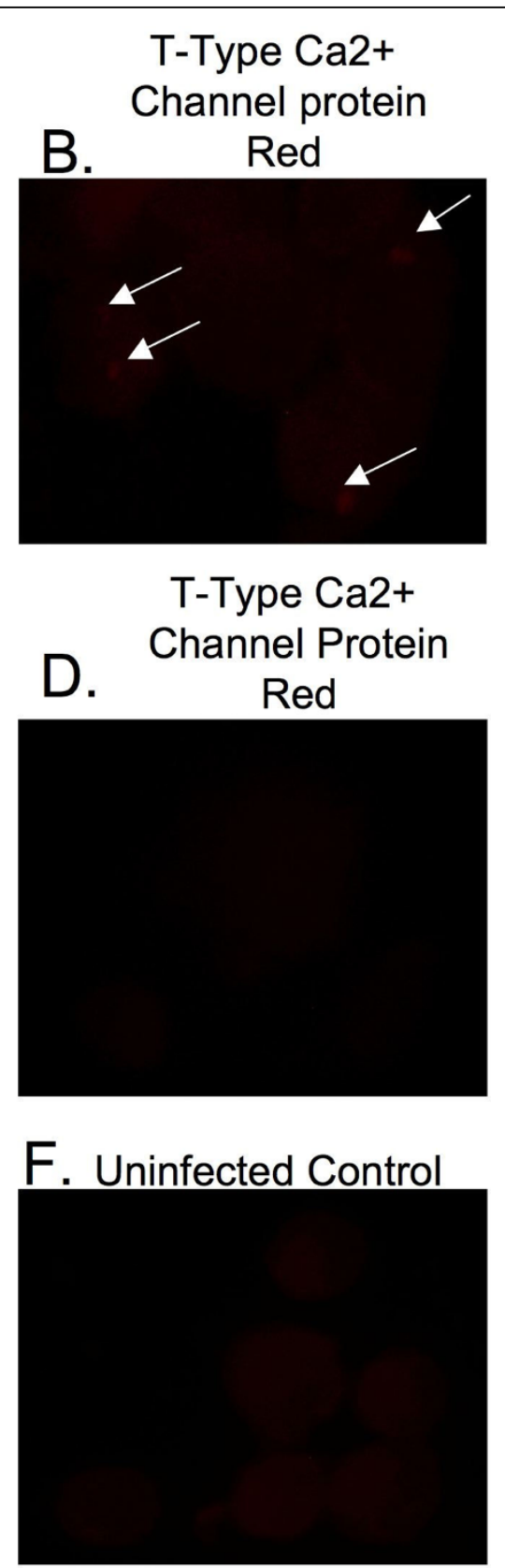

We studied protein expression of the mycobacterial phagosome and compared it to a isogenic mutant. We identified several proteins, either previously described or not reported to be present on the phagosomes. The modifications appear to have a significant effect on the intravacuolar environments. Nonetheless, the use of the MAV_2928 mutant established the possibility that one protein may have key function in modulating the formation of the phagosome, perhaps by altering initial 

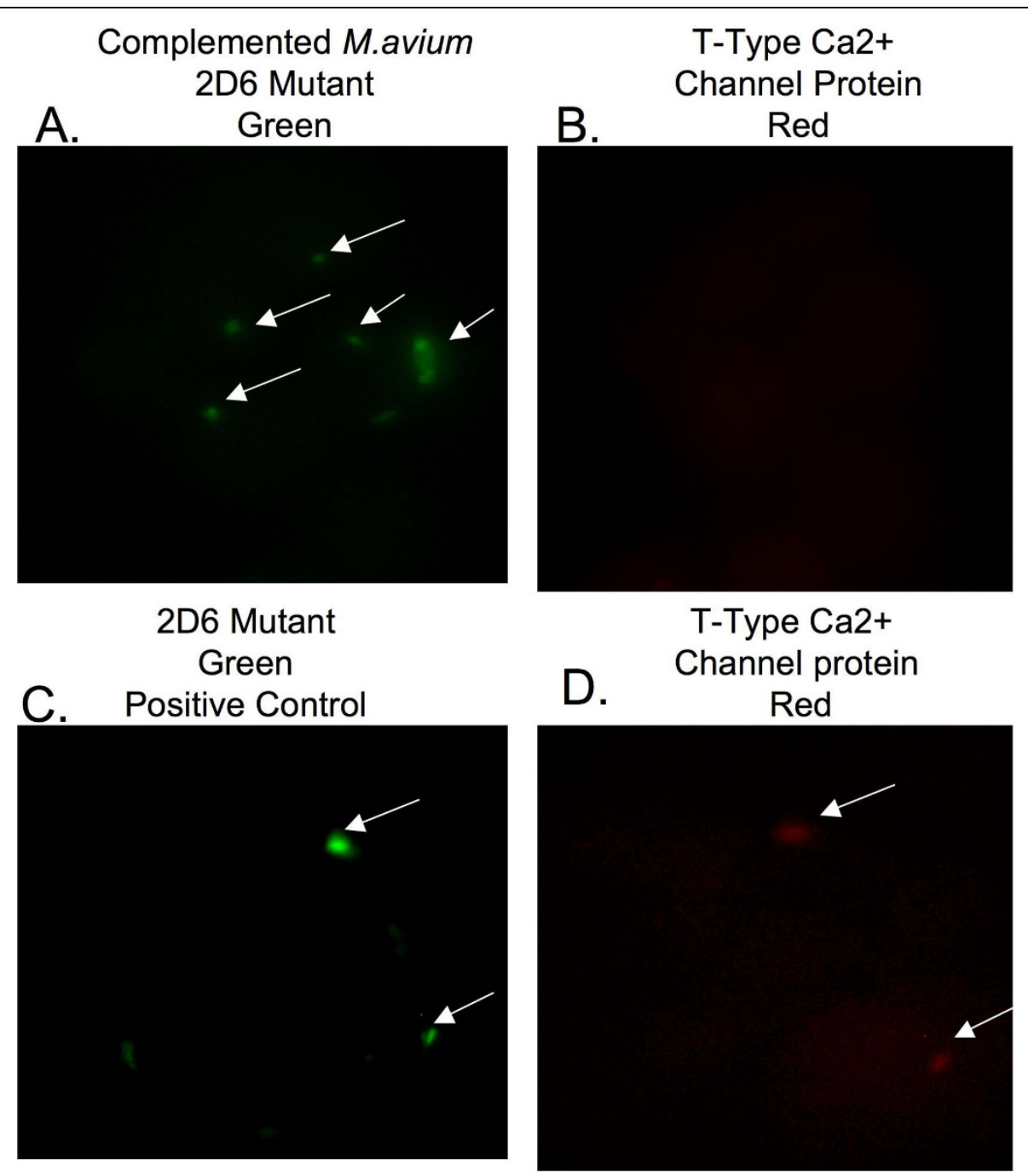

Figure 7 Fluorescent microscopy images of U937 macrophages infected with fluorescein-labeled complemented 2D6 mutant. The Ttype $\mathrm{Ca}^{++}$channel protein is labeled by antibody conjugated with Texas red. The arrows point to the bacteria (green) and $\mathrm{T}$-type $\mathrm{Ca}{ }^{++}$channel protein (red) (A-D).

events. Alternatively, the PPE-PE operon may be part of a complex system influencing or impacting the expression of other bacterial genes or involved in the transport of bacterial proteins. Change in single element concentrations in the bacterial environment can have significant effect on gene regulation [45]. Future studies will address some of the differences found and will possibly provide insights into the mechanisms of pathogenesis and survival of mycobacteria inside the host.

\section{Conclusion}

1. Inactivation of MAV_2928 alters early stages of macrophage transcription in response to MAC infection.

2. Absence of MAV_2928 affects the concentration of materials inside the MAC vacuole, indicating changes in the transport mechanisms.
3. Investigation of the phagosome membrane components revealed unexpected results for the action of only one protein, suggesting that MAV_2928 may be involved in the transport of other proteins into the host cell.

4. Future studies will attempt to identify proteins that are secreted by the PPE MAV_2928-dependent mechanism.

\section{Methods}

Bacterial strains and growth conditions

Mycobacterium avium strain 109 (MAC 109), a virulent strain in mice initially isolated from blood of a patient with AIDS, was cultured from $20 \%$ glycerol stock onto Middlebrook 7H11 agar supplemented with oleic acid, albumin, dextrose and catalase (OADC; Hardy 

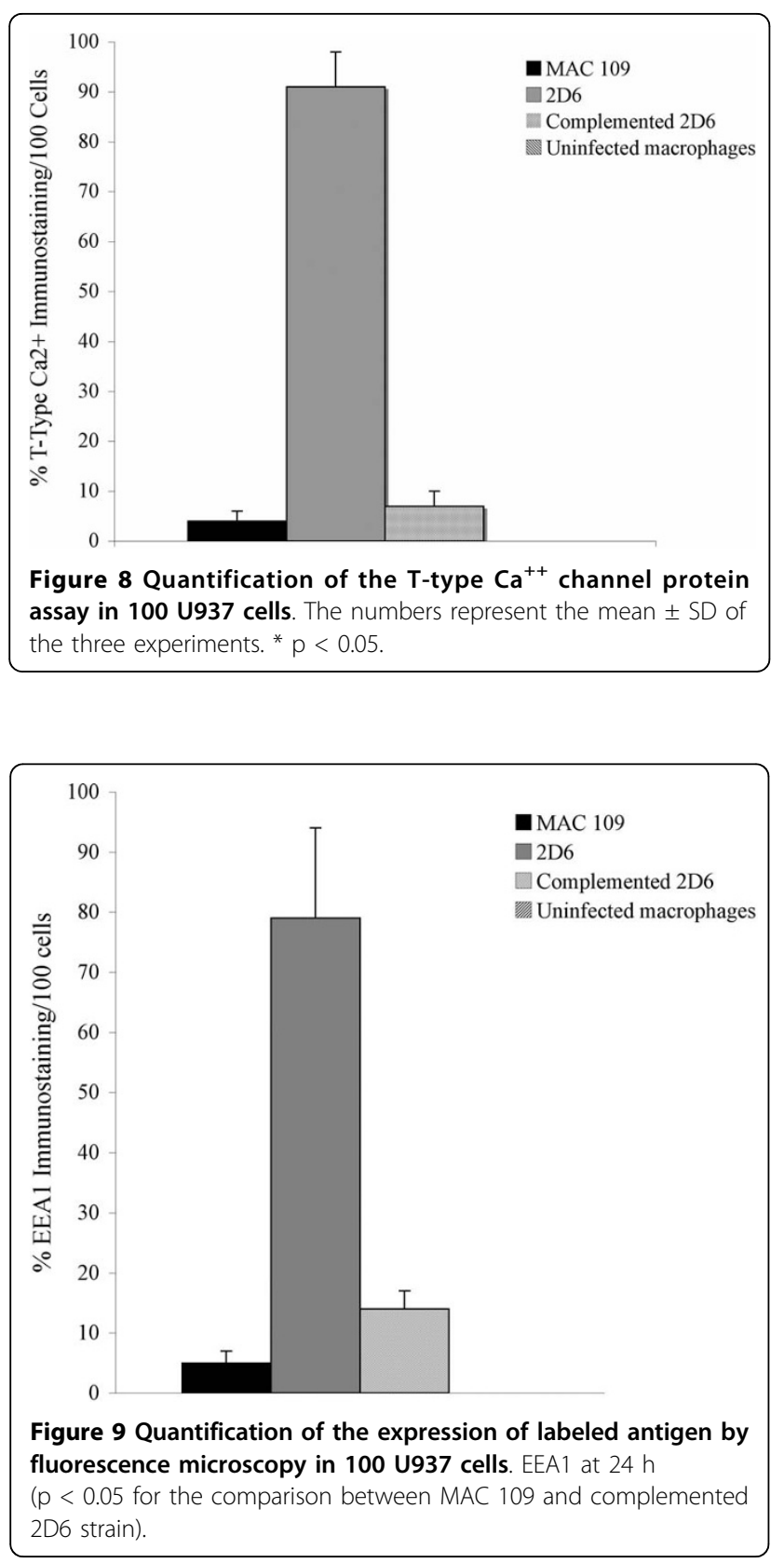

Diagnostics, Santa Maria, CA) at $37^{\circ} \mathrm{C}$ for 21 days. For the assays, bacteria were suspended in Hank's buffered salt solution (HBSS) and passed through a 26-gauge needle 10 times to disperse clumps. The suspension was then allowed to rest for $5 \mathrm{~min}$ and the upper half was used for the assays. The bacterial concentration was adjusted to $1 \times 10^{8}$ bacteria $\mathrm{ml}^{-1}$ using a McFarland standard. Microscopic observations of the suspensions were carried out to verify dispersion of bacteria. Only well dispersed inocula were used in the described experiments. The 2D6 mutant was cultured from 20\% glycerol stock on Middlebrook 7H11 agar containing $400 \mu \mathrm{g} / \mathrm{ml}$ kanamycin. The 2D6 mutant suspension was

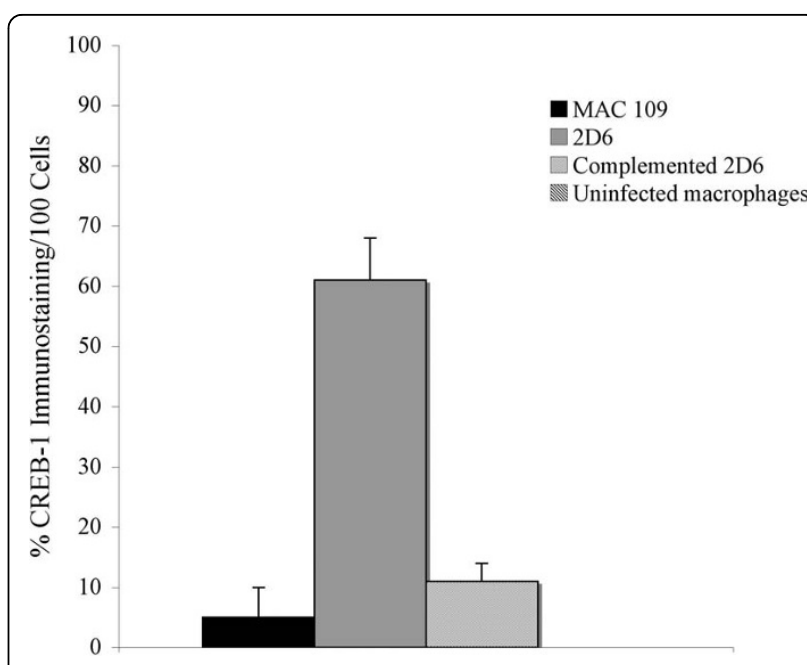

Figure 10 Quantification of the expression of labeled antigen by fluorescence microscopy in 100 U937 cells. CREB-1 at $24 \mathrm{~h}$ $(p<0.05$ for the comparison between MAC 109 and complemented 2D6 strain).

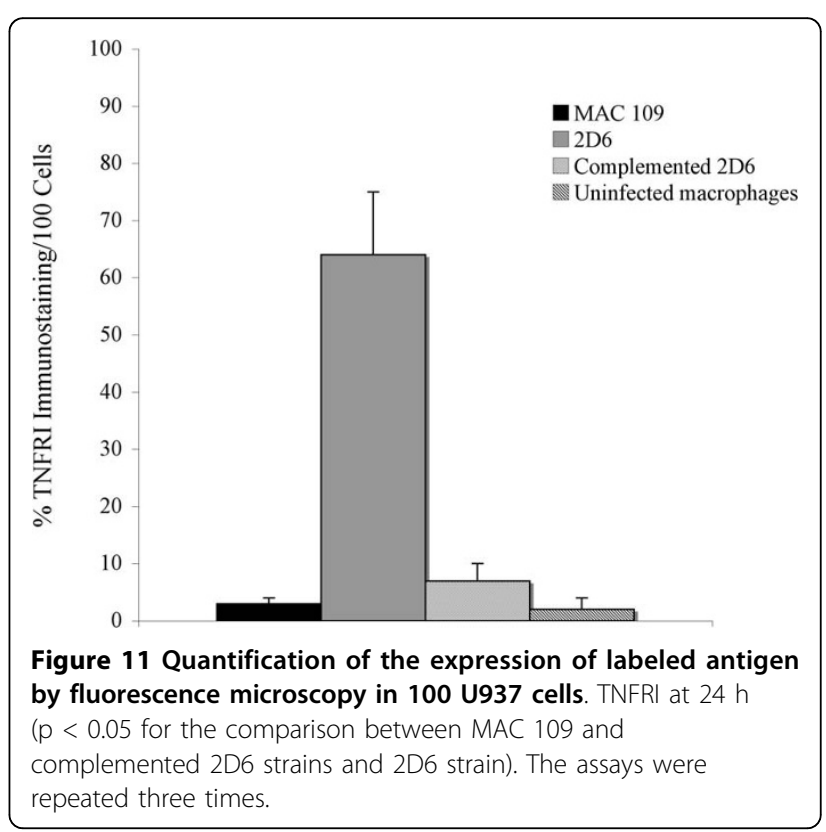

made as described above. The complemented 2D6 strain [11] was also cultured from $20 \%$ glycerol stock and grown on Middlebrook 7H11 agar plates containing 200 $\mu \mathrm{g} / \mathrm{ml}$ apramycin [11].

\section{Cells and culture conditions}

Human monocytic cell line U937 (ATCC CRL-1593.2) was cultured in RPMI-1640 (Gibco Laboratories) supplemented with $10 \%$ heat-inactivated fetal bovine serum (FBS; Sigma Chemical), $2 \mathrm{mM}$ L-glutamine. The U937 cells were used between passages 15 to 20 and concentrations of $7 \times 10^{6}$ were seeded in $75 \mathrm{~cm}^{2}$ flasks. The cell line was chosen because of convenience, since the 


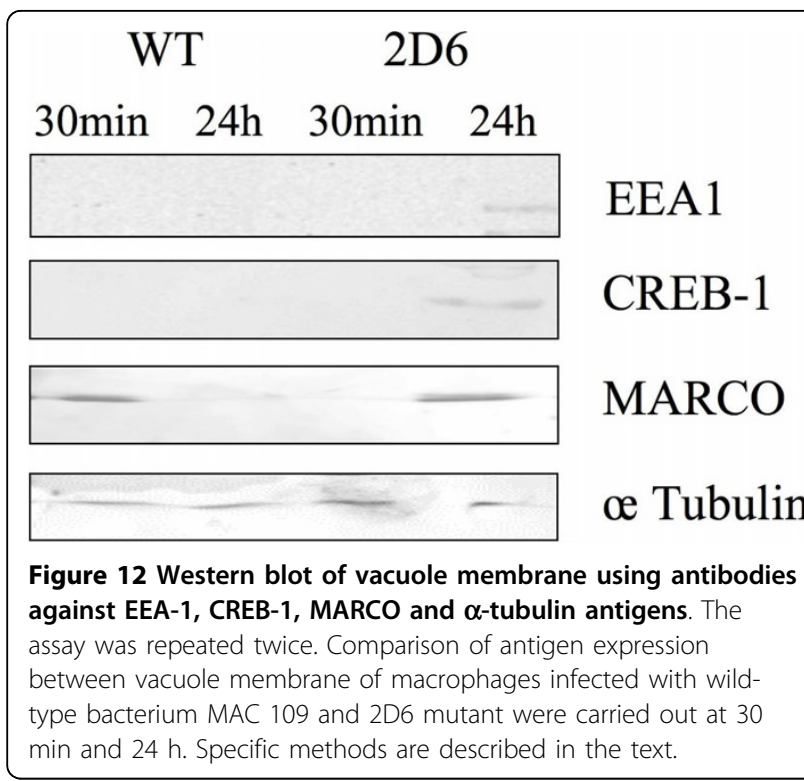

Table 4 Concentrations of single elements in phagosomes of macrophages infected with $M$. avium wild-type (WT) or 2D6 mutant

\begin{tabular}{|c|c|c|c|c|}
\hline \multirow{2}{*}{$\begin{array}{l}\text { Element } \\
\text { (Unit) }\end{array}$} & WT & 2D6 & WT & $2 \mathrm{D6}$ \\
\hline & \multicolumn{2}{|c|}{1 hour } & \multicolumn{2}{|c|}{24 hours } \\
\hline \multirow[t]{2}{*}{$\mathrm{P}(\mathrm{CPM})$} & 0.013964 & 0.0144769 & 0.010927 & 0.0072144 \\
\hline & \multicolumn{2}{|c|}{$(p>0.05)$} & \multicolumn{2}{|c|}{$(p>0.05)$} \\
\hline \multirow[t]{2}{*}{$S(C P M)$} & 0.01848 & 0.0210543 & 0.035871 & 0.0099751 \\
\hline & \multicolumn{2}{|c|}{$(p>0.05)$} & \multicolumn{2}{|c|}{$(p>0.05)$} \\
\hline \multirow[t]{2}{*}{$\mathrm{Cl}(\mathrm{CPM})$} & 0.151509 & 0.2305818 & 0.244938 & 0.1115413 \\
\hline & \multicolumn{2}{|c|}{$(p>0.05)$} & \multicolumn{2}{|c|}{$(p>0.05)$} \\
\hline \multirow[t]{2}{*}{$\mathrm{K}\left(\mu \mathrm{g} / \mathrm{cm}^{2}\right)$} & 0.143707 & 0.3204288 & 0.021604 & 0.1759281 \\
\hline & \multicolumn{2}{|c|}{$(p=0.05)$} & \multicolumn{2}{|c|}{$(p=0.0009)$} \\
\hline \multirow[t]{2}{*}{$\mathrm{Ca}\left(\mu \mathrm{g} / \mathrm{cm}^{2}\right)$} & $6.5 \times 10^{-5}$ & 0.0329014 & 0.010014 & 0.0224007 \\
\hline & \multicolumn{2}{|c|}{$(p=0.821)$} & \multicolumn{2}{|c|}{$(p=0.00492)$} \\
\hline \multirow[t]{2}{*}{$M n\left(\mu \mathrm{g} / \mathrm{cm}^{2}\right)$} & $6.5 \times 10^{-5}$ & 0.00018 & 0.000133 & $8.204 \times 10^{-5}$ \\
\hline & \multicolumn{2}{|c|}{$(p=0.0308)$} & \multicolumn{2}{|c|}{$(p=0.302)$} \\
\hline \multirow[t]{2}{*}{$\mathrm{Fe}\left(\mu \mathrm{g} / \mathrm{cm}^{2}\right)$} & 0.00167 & 0.0054284 & 0.006516 & 0.0022057 \\
\hline & \multicolumn{2}{|c|}{$(p=0.3025)$} & \multicolumn{2}{|c|}{$(p=0.12196)$} \\
\hline \multirow[t]{2}{*}{$\mathrm{Cu}\left(\mu \mathrm{g} / \mathrm{cm}^{2}\right)$} & 0.000183 & 0.1394013 & 0.000112 & 0.0148152 \\
\hline & \multicolumn{2}{|c|}{$(p>0.05)$} & \multicolumn{2}{|c|}{$(p>0.05)$} \\
\hline \multirow[t]{2}{*}{$\mathrm{Zn}\left(\mu \mathrm{g} / \mathrm{cm}^{2}\right)$} & 0.00088 & 0.015652 & 0.000792 & 0.005898 \\
\hline & \multicolumn{2}{|c|}{$(p=0.00517)$} & \multicolumn{2}{|c|}{$(p=0.02767)$} \\
\hline
\end{tabular}

Complemented 2D6 mutant had similar results to the wild-type bacterium. $\mathrm{Y}=\mathrm{Yes} ; \mathrm{N}=$ No

strains grow similarly in U937, THP-1 and monocytederived macrophages. The U937 was the cell line that allowed the purification of the greater number of vacuoles [11]. The cells were grown to $90-100 \%$ confluency and allowed to differentiate overnight by incubation with $500 \mathrm{ng} \mathrm{ml}^{-1}$ phorbol 12-myristate 13-acetate
Table 5 Sense and antisense primers for real-time PCR

\begin{tabular}{ccc}
\hline Target & \multicolumn{1}{c}{ Primers } & PCR product (bp) \\
\hline 3-actin & 5'-TGATGGTGGGCATGGGTCAGA-3' & 800 \\
& 5'-CCCATGCCAATCTCATCTTGT-3' & \\
GRK4 & 5'-AATGTATGCCTGCAAAAAGC-3' & 235 \\
& 5'-GATTGCCCAGGTTGTAAATG-3' & \\
DGKD & 5'-CTCGGCTTACGGTTATTCCAG-3' & 656 \\
& 5'-CCATCTCCATCTTCAGCCTCC-3' & \\
LCP2 & 5'-CACTGAGGAATGTGCCCTTTC-3' & 408 \\
& 5'-GTGCCTCTTCCTCCTCATTGG-3' & \\
\hline
\end{tabular}

Complemented 2D6 mutant had similar results to the wild-type bacterium. $\mathrm{Y}=\mathrm{Yes} ; \mathrm{N}=\mathrm{No}$

(PMA; Sigma). Human monocyte-derived macrophages and U937 were shown to behave similarly when infected with $M$. avium wild-type and 2D6 mutant [11]. The MAC 109 or 2D6 mutant were added to the monolayers at a multiplicity of infection (MOI) of 10 , and the infection was allowed to take place for $2 \mathrm{~h}$ at $37^{\circ} \mathrm{C}$ in $5 \%$ $\mathrm{CO}_{2}$. The supernatant was then removed and the cell monolayer was washed three times with HBSS. The tissue culture medium was then replenished.

\section{RNA extraction}

For the DNA microarray, the U937 infection assay for MAC 109, 2D6 mutant, and the complemented 2D6 mutant followed by RNA isolation was carried out as described previously [46]. Briefly, U937 monolayers of approximately $10^{8}$ cells were infected with MAC 109 or 2D6 $\left(1 \times 10^{8}\right.$ concentration) for $4 \mathrm{~h}$. The cells were washed to remove extracellular bacteria and total RNA was isolated using Atlas Pure Total RNA Labeling System (Clontech Laboratories, Palo Alto, CA) according to the manufacturer's instructions. The resultant RNA was treated with DNase for $30 \mathrm{~min}$ at $37^{\circ} \mathrm{C}$ followed by phenol-chloroform extraction and precipitation with ethanol. The RNA was run on 1\% denaturing agarose gel and quantified by UV spectrometer at $260 / 280 \mathrm{~nm}$. RNA was then submitted to analysis using the bioanalyzer at the Center for Genome and Biotechnology Research at OSU.

To confirm the expression, as well as to determine the relative transcriptional levels of G-protein coupled receptor kinase 4 (GRK-4), diacylglycerol kinase delta (DGKD) and lymphocyte cytosolic protein 2 (LCP2) by real-time PCR, similar U937 infection assay was performed as described above and modifications in the RNA extraction method were made. After $4 \mathrm{~h}$, the monolayers were washed with HBSS, scraped and collected in a $50 \mathrm{ml}$ falcon tube and placed on ice. The cells were centrifuged at $500 \mathrm{rpm}$ for $5 \mathrm{~min}$ to remove any residual extracellular bacteria. Then, $2 \mathrm{ml}$ of Trizol (Invitrogen, Carlsbad, CA) was added to the falcon tube. The suspension was then passed 20 times through a 21- 
gauge needle to lyse the mononuclear cells. The lysate was then centrifuged at $\max (14,000) \mathrm{rpm}$ at $4^{\circ} \mathrm{C}$. The supernatant was then transferred to heavy Lock Gel I (Eppendorf, NY), and to it chloroform:isoamyl alcohol (24:1) (Sigma) was added and mixed. After centrifugation, the aqueous phase was precipitated in isopropanol followed by $75 \%$ ethanol wash to remove isopropanol. The DNase treatment of total RNA was carried out before probe synthesis using the protocol described by the Atlas Pure Total RNA Labeling System (Clontech, Mountain View, CA). The quality of RNA was verified on a $1 \%$ denaturing agarose gel, and the concentration was calculated based on the absorbance at $260 \mathrm{~nm}$.

The cDNA was synthesized as per the protocol described by Invitrogen (Carlsbad, CA). Total RNA (5 $\mu \mathrm{g})$ with oligo $(\mathrm{dT})_{20}$ and $\mathrm{dNTP}$ mix was incubated at $65^{\circ} \mathrm{C}$ for $5 \mathrm{~min}$ and cooled on ice for $1 \mathrm{~min}$. For each total RNA sample, $10 \mu \mathrm{l}$ cDNA synthesis mix was made: $10 \times$ RT buffer, $25 \mathrm{mM} \mathrm{MgCl} 2,0.1 \mathrm{M} \mathrm{DTT}, 40 \mathrm{U} / \mu \mathrm{l}$ RNaseOUT and $200 \mathrm{U} / \mu \mathrm{l}$ Superscript III RT. The samples were mixed gently and collected by brief centrifugation. Then, the samples were incubated in a thermal cycler at $42^{\circ} \mathrm{C}$ for $50 \mathrm{~min}$ and the reaction was terminated at $70^{\circ} \mathrm{C}$ for $15 \mathrm{~min}$ and cooled on ice. Finally, the reactions were collected by brief centrifugation, and $1 \mu \mathrm{l}$ of RNase $\mathrm{H}$ was added to each sample and incubated for $20 \mathrm{~min}$ at $37^{\circ} \mathrm{C}$. The cDNA prepared was used for real-time PCR.

\section{DNA microarray}

The ${ }^{32}$ P-labeled cDNA probes were prepared using the Atlas Pure Total RNA Labeling System (Clontech Laboratories) as previously described [46]. This array was the only one available commercially when the experiments were performed. In brief, $5 \mu \mathrm{g}$ of total RNA was reverse transcribed using the primer mix supplied with each array. The mixture was heated to $65^{\circ} \mathrm{C}$ for $2 \mathrm{~min}$ in a PCR thermal cycler, followed by $50^{\circ} \mathrm{C}$ for $2 \mathrm{~min}$ in presence of a master mix containing $5 \times$ Reaction buffer, dNTP, and dATP. The DTT and MMLV reverse transcriptase was added, mixed and incubated for $25 \mathrm{~min}$ at $50^{\circ} \mathrm{C}$. Then, $10 \times$ termination mix was added to end the reaction. Unincorporated nucleotides were removed using a Nucleospin Extraction Spin Column (Clontech Laboratories, Palo Alto, CA) as per the manufacturer's instructions. Scintillation counting was done to measure the incorporation of radionucleotide into the probe.

The Clontech Human Nylon Filter Arrays (Clontech Laboratories), containing DNA sequences for 1,500 genes, were prehybridized in $5 \mathrm{ml}$ of Express-Hyb solution supplemented with $0.5 \mathrm{mg}$ salmon testes DNA at $68^{\circ}$ $\mathrm{C}$ for $30 \mathrm{~min}$. The radiolabeled cDNA probe was heated in a boiling water bath for $2 \mathrm{~min}$, followed by $2 \mathrm{~min}$ on ice. Then it was added to the hybridization solution and allowed to hybridize to the filter array overnight. The membranes were washed in SSC plus $0.1 \%$ sodium dodecyl sulphate (SDS) at $68^{\circ} \mathrm{C}$ for $30 \mathrm{~min}$ and further rinsed in SSC for $5 \mathrm{~min}$ at room temperature. Next, the filters were wrapped in plastic wrap and exposed to a phosphor imaging screen for $24 \mathrm{~h}$. Analysis of the phosphor imaging screens was done by using a phosphor imager (Perkin Elmer, Boston, MA) and AtlasImage 2.0 software. Global normalization method was used, by the background subtraction method followed by SAM analysis. For most of the genes, a $Q$ value (percent change that the gene is false-positive) of $5 \%$ was used as the cut-off value. The quality of the hybridization signals was assessed using scatter plot analysis of replicate samples, as well as by calculating the coefficient of variance. Only samples with hybridizations with high correlation levels $(\mathrm{p}>0.9)$ among replicates were used for subsequent analysis. The following genes were used as housekeeping genes: glyceraldehyde 3-phosphate dehydrogenase (GAPDH), tubulin alpha 1 (TUBA1), hypoxanthine-guanine phosphoribosyltransferase 1 (HPRT1), major histocompatibility class $1 \mathrm{C}$ (HLAC), beta-actin (ACTB) and 23-kDa highly basic protein (PRL13A). Only genes that showed differential expression at least by two-fold were incorporated in the results.

\section{Real-time PCR}

Genes were chosen randomly for real-time PCR analysis, and SYBR technology was used. Run protocol for the LightCycler was as follows: denaturation $95^{\circ} \mathrm{C}$ for $5 \mathrm{~min}$; amplification and quantification repeated for 35 times: $95^{\circ} \mathrm{C}$ for $30 \mathrm{sec}, 59^{\circ} \mathrm{C}$ for $30 \mathrm{sec}$ and $72^{\circ} \mathrm{C}$ for $1 \mathrm{~min}$ with one fluorescence measurement followed by $72^{\circ} \mathrm{C}$ for $5 \mathrm{~min}$ and $4^{\circ} \mathrm{C}$. Table 5 shows the sense and antisense plasmid.

The threshold cycle $(\mathrm{Ct})$ is defined as the fractional cycle number at which the fluorescence reaches $10 \times$ the standard deviation of the baseline and was quantified as described in User Bulletin \#2 for ABI PRIMS 7700 sequence detection system (ABI). The fold change in gene expression was determined using an amplificationbased strategy. For each gene amplification, before calculating the fold change, the $\mathrm{Ct}$ values were normalized to the $\mathrm{Ct}$ of $\beta$-actin using the following formula:

$$
\begin{aligned}
& \text { Fold Change }=2^{-\Delta(\Delta \mathrm{Ct})} \text { where } \\
& \Delta \mathrm{Ct}=\mathrm{Ct}{ }_{\text {target }}-\mathrm{Ct}, \beta-\mathrm{Actin}, \Delta(\Delta \mathrm{Ct})=\Delta \mathrm{Ct} \text {, expressed }-\Delta \mathrm{Ct} \text {, control }
\end{aligned}
$$

Quantitative analysis was performed using iCycler I software (BIORAD, Hercules, CA). A relative quantification was used in which the expression levels of macrophage target genes were compared to data from a standard curve generated by amplifying several dilutions 
of a known quantity of amplicons. Real-time PCR efficiency was determined using a dilution series of cDNA template with a fixed concentration of the primers. Slopes calculated by the LightCycler software were used to calculate efficiency using the following formula: $\mathrm{E}=10^{(-1 / \text { slope })}$. These calculations indicated high realtime efficiency with a high linearity. Because expression of $\beta$-actin is constant, independent of conditions, target genes from both control and experimental groups were normalized to the expression level of the $\beta$-actin gene.

\section{Phagosome isolation and microscopy}

Phagosomes containing M. avium 109 and 2D6 mutant were isolated according to a protocol described previously [4], with minor modifications [11]. Briefly, infected macrophages were added to homogenization buffer and scraped from tissue culture flasks. The cells were lysed by approximately 30 passages through a tuberculin syringe (at least $90 \%$ of the cells were lysed), and the lysate was carefully deposited over a $12 \%$ to $15 \%$ sucrose gradient. The preparation was then centrifuged at $2000 \mathrm{rpm}$ for $40 \mathrm{~min}$ at $4^{\circ} \mathrm{C}$. After centrifugation, the interface was collected and centrifuged in $10 \%$ Ficoll solution at $2500 \mathrm{rpm}$ for $40 \mathrm{~min}$ at $4^{\circ} \mathrm{C}$. A small pellet containing phagosomes was visible at the bottom of the tube. Phagosomes were analyzed for purity visually on glass slides by staining MAC 109 or 2D6 prior to infection with $10 \mu \mathrm{g} / \mathrm{ml} \mathrm{N}$-hydroxysuccinimidyl ester 5-(and-6)-carboxyfluorescein (NHS-CF; Molecular Probes, Eugene, OR) for $1 \mathrm{~h}$ at $37^{\circ} \mathrm{C}$. Phagosomes containing live $M$. avium or 2D6 showed green fluorescein stain when observed under $100 \times$ oil immersion (Leica DMLB Scope, Spot $3^{\text {rd }}$ Party Interface; Diagnostics Instruments Inc.). Approximately $98 \%$ of the phagosomes observed showed bacteria in them.

\section{Mass spectrometry}

The phagosome samples were run by $\mathrm{lc} / \mathrm{ms}$-ms using a Waters (Milford, MA) NanoAcquity HPLC connected to a Waters Q-TOF Ultima Global. Phagosome preparation, isolated as described above, was treated using the In-Gel Tryptic Digestion Kit from Pierce (Rockford, IL), according to instructions provided by the manufacturer. Briefly, the phagosome preparation was treated with activated trypsin for $15 \mathrm{~min}$ at room temperature. The suspension was transferred to $37^{\circ} \mathrm{C}$ for $4 \mathrm{~h}$. The digestion mixture was then placed in a clean tube. To further extract peptides, $10 \mu \mathrm{l}$ of $1 \%$ trifluoroacetic acid was added for $5 \mathrm{~min}$. Five microliters of a sample was loaded onto a Waters Symmetry C18 trap at $4 \mu \mathrm{l} / \mathrm{min}$, then the peptides were eluted from the trap onto the $10 \mathrm{~cm} \times 75$ $\mu \mathrm{m}$ Waters Atlantis analytical column at $350 \mathrm{nl} / \mathrm{min}$. The HPLC gradient went from $2 \%$ to $25 \% \mathrm{~B}$ in $30 \mathrm{~min}$, then to $50 \% \mathrm{~B}$ in $35 \mathrm{~min}$, then $80 \% \mathrm{~B}$ in $40 \mathrm{~min}$ and held there for $5 \mathrm{~min}$. Solvent A was $0.1 \%$ formic acid in water, and $B$ was $0.1 \%$ formic acid in acetonitrile. Peptide "parent ions" were monitored as they eluted from the analytical column with $0.5 \mathrm{sec}$ survey scans from m/ z 400-2000. Up to three parent ions per scan with sufficient intensity and 2,3 , or 4 positive charges were chosen for $\mathrm{ms} / \mathrm{ms}$. The $\mathrm{ms} / \mathrm{ms}$ scans were $2.4 \mathrm{sec}$ from $\mathrm{m} / \mathrm{z}$ 50-2000.

The mass spectrometer was calibrated using the ms/ ms spectrum from glu-fibrinopeptide. Masses were corrected over the time the calibration was used (one day or less), using the Waters MassLynx DXC system.

The raw data were processed with MassLynx 4.0 to produce pkl files, a set of smoothed and centroided parent ion masses with the associated fragment ion masses. The pkl files were searched with Mascot 2.0 (Matrix Science Ltd., London, UK) database searching software, using mass tolerances of 0.2 for the parent and fragment masses. The Swiss Prot database was used, limiting the searches to human proteins. Peaks Studio (Bioinformatics Solutions Inc., Ontario, Canada) was also used to search the data, using mass tolerances of 0.1 , and the IPI human database.

The proteomic analysis was compared to the protein profile of bacteria grown on $7 \mathrm{H} 10$ plates. Then, if the protein expression was increased or decreased at least 1.5 -fold, the data were included. Proteins or peptides to be included in the analysis had to be present in both runs. Proteins present in only one run were not included.

\section{Immunofluorescence analysis}

Because some of the proteins identified in the phagosomes have not been previously described as part of the vacuole membrane, we attempted to confirm their presence by using immunofluorescence. Primary antibodies against pulmonary surfactant protein D (SP-D), T-type $\mathrm{Ca}^{++}$alpha1I protein, EEA-1, CREB-1, MARCO and $\alpha-$ tubulin were purchased from Santa Cruz Biotechnology, Santa Cruz, CA. Primary antibodies used were from rabbit, except the goat anti-T-type $\mathrm{Ca}^{++}$alpha1I. Secondary antibodies were Texas-Red conjugates (TR) and included donkey anti-rabbit IgG-TR (Amersham Biosciences, Piscataway, NJ) and mouse anti-goat IgG-TR (Santa Cruz Biotechnology, Santa Cruz, CA). The twochamber slides from Nalge Nunc (Rochester, NY) were employed for macrophage monolayer preparation and fluorescence microscopy. The numbers of U937 cells were determined in a hemocytometer before seeding. A total of $5 \times 10^{5}$ cells were added in each tissue culture well of the two-chamber slides and were differentiated with $2 \mu \mathrm{g} / \mathrm{ml}$ of PMA overnight. The monolayers were then infected with MAC 109, 2D6 or the complemented 2D6 mutant labeled with NHS-CF as described above 
using a MOI of 10 . The cells were incubated for $4 \mathrm{~h}$ at $37^{\circ} \mathrm{C}$ for SP-D protein expression and $24 \mathrm{~h}$ for T-type $\mathrm{Ca}^{++}$alpha1I protein expression. The time points were chosen based on the expression results. The chambers were washed three times with sterile phosphate buffer saline (PBS) and treated with $200 \mu \mathrm{g} / \mathrm{ml}$ amikacin to kill extracellular bacteria. The cells were subsequently washed and allowed to air dry. Cells were then fixed with $2 \%$ paraformaldehyde for $1 \mathrm{~h}$ at room temperature, permeabilized in cold $0.1 \%$ Triton X-100 (J.T. Baker) and $0.1 \%$ sodium citrate for $20 \mathrm{~min}$ on ice. Next, the monolayers were washed with PBS and blocked with $2 \%$ BSA (BSA, Sigma) in PBS for 20 min at room temperature. The $2 \%$ BSA was replaced with $1 \mathrm{ml}$ of specific primary antibody and allowed to incubate for $1 \mathrm{~h}$. All the antibodies were prepared in 2\% BSA in PBS to prevent non-specific binding. The cells were then washed three times with sterile PBS and re-incubated with the appropriate Texas-Red conjugated secondary antibody for an additional $1 \mathrm{~h}$. Macrophages were washed three times with sterile PBS and allowed to air dry before adding Aqua-mount mounting media (Lerner laboratories, Pittsburgh, PA) and cover slips (Corning, Corning, NY). Cell preparations were visualized with a Leica DMLB microscope. The microscope was operated by Spot $3^{\text {rd }}$ Party Interface Software with a Photoshop CS version 8.0 on a Macintosh OS (version 4.0.9) based system.

\section{Immunoprecipitation and Western blot}

The U937 cells were infected with $M$. avium wild-type or 2D6 mutant with MOI 1 cell:100 bacteria in $75 \mathrm{mc}^{2}$ flasks. After $30 \mathrm{~min}$ and $24 \mathrm{~h}$ following infections, monolayers were lysed and phagosomes were extracted as directed above. Equal amounts of phagosomal proteins were incubated with $10 \mu \mathrm{l}$ of primary antibodies and 30 $\mu \mathrm{l}$ protein $\mathrm{A} / \mathrm{G}$ Plus-agarose beads at $4{ }^{\circ} \mathrm{C}$ overnight with continuous agitation. Next day, beads were washed three times with PBS, and the captured proteins were resolved on a $12 \%$ SDS-PAGE gel. Proteins were transferred into a nitrocellulose membrane and blocked overnight with Odyssey blocking buffer (Li-Cor) in TBS (Tris-buffered saline). The membranes were probed with EEA1, CREB1, MARCO and $\alpha$-tubulin antibodies (Santa Cruz Biotechnology) for $1 \mathrm{~h}$ and after, incubated with appropriate secondary antibodies (Li-Cor) in TBS for $1 \mathrm{~h}$. Proteins were visualized by scanning of the membranes in the Odyssey Imager (Li-Cor, Lincoln, NE).

\section{Concentration of single elements in the phagosome}

Human monocyte-derived macrophages were purified as previously described $[17,28]$, seeded on 200-mesh Formvar-coated London finder gold grids (Electron Microscopy Sciences) and cultured in RPMI-1640 supplemented with $10 \%$ FBS. The monolayers were infected with mycobacteria (MOI 10) for $1 \mathrm{~h}$ and subsequently washed with PBS. The monolayers were maintained in culture for $1 \mathrm{~h}$ or $24 \mathrm{~h}$, then fixed and prepared for $\mathrm{x}$ ray microscopy, as previously reported $[17,44]$, and the phagosome was obtained $[17,44,45]$.

Elemental maps were extracted from x-ray fluorescence spectra, using the software package MAPS [47], and quantification was achieved by measuring $\mathrm{x}$-ray fluorescence from NIST thin-film standards NBS 1832 and NBS 1833 (National Bureau of Standards, Gaithersburg, MD, USA), prior to, during, and after the experiments. Calibration curves and calculations were carried out as described $[17,44,45]$. Statistical analysis of observed elemental changes was performed by comparing the concentration of the respective elements using Student's- $t$ test. A p $<0.05$ was considered significant.

\section{Statistical analysis}

Comparisons between control and experimental groups were submitted to statistical analysis to determine the significance. Statistical analysis of the means \pm SD was determined by ANOVA. A $\mathrm{p}<0.05$ was considered significant. A DNA microarray was carried out three independent times, while the proteomic analysis of vacuole proteins was performed twice.

\section{Acknowledgements}

We are grateful for the support of the Mass Spectrometry Core Facility of the Environmental Health Sciences Center, Oregon State University, and from grant number P30 ES00210, from National Institute of Environmental Health Sciences, National Institutes of Health. This work was also supported by the NIH grants \# Al47010 and Al043199.

We thank Denny Weber for help in preparing the manuscript.

\section{Author details}

${ }^{1}$ Department of Biomedical Sciences, College of Veterinary Medicine, Oregon State University, Corvallis OR 97331, USA. ${ }^{2}$ Department of Internal Medicine II -Infectious Diseases, University of Freiburg, 79106 Freiburg, Germany. ${ }^{3}$ Argonne National Laboratory, Argonne, Illinois, USA. ${ }^{4}$ Geron Corporation, 230 Constitution Drive, Menlo Park, CA 94025, USA. ${ }^{5}$ Department of Respiratory and Infectious Diseases, Shinshu University School of Medicine, 3-1-1 Asahi, Matsumoto, 390-8621, Japan. 'Department of Microbiology, College of Science, Oregon State University, Corvallis OR 97331, USA.

\section{Authors' contributions}

SJ performed the proteomics, some of the DNA microarray, wrote the initial paper.

LD participated in all the steps of the paper.

DW, JM, IM, BL performed the x-ray microscopy.

$Y L$ participated in the microarray.

YY participated in the proteomic studies.

LEB directed the studies, helped in macrophage experiments, senior author. All authors read and approved the final manuscript.

Received: 30 September 2009 Accepted: 1 April 2010 Published: 1 April 2010

\section{References}

1. Falkinham JO: Epidemiology of infection by nontuberculous mycobacteria. Clin Microbiol Rev 1996, 9(2):177-215.

2. Inderlied CB, Kemper CA, Bermudez LE: The Mycobacterium avium complex. Clin Microbiol Rev 1993, 6(3):266-310. 
3. Aksamit TR: Mycobacterium avium complex pulmonary disease in patients with pre-existing lung disease. Clin Chest Med 2002, 23(3):643-653.

4. Sturgill-Koszycki S, Schlesinger PH, Chakraborty $\mathrm{P}$, Haddix $\mathrm{PL}$, Collins $\mathrm{HL}$, Fok AK, Allen RD, Gluck SL, Heuser J, Russell DG: Lack of acidification in Mycobacterium phagosomes produced by exclusion of the vesicular proton-ATPase. Science 1994, 263(5147):678-681.

5. Oh YK, Straubinger RM: Intracellular fate of Mycobacterium avium: use of dual-label spectrofluorometry to investigate the influence of bacterial viability and opsonization on phagosomal $\mathrm{pH}$ and phagosome-lysosome interaction. Infect Immun 1996, 64(1):319-325.

6. Via LE, Deretic D, Ulmer RJ, Hibler NS, Huber LA, Deretic V: Arrest of mycobacterial phagosome maturation is caused by a block in vesicle fusion between stages controlled by rab5 and rab7. J Biol Chem 1997, 272(20):13326-13331

7. Beuzon CR, Meresse S, Unsworth KE, Ruiz-Albert J, Garvis S, Waterman SR, Ryder TA, Boucrot E, Holden DW: Salmonella maintains the integrity of its intracellular vacuole through the action of SifA. Embo J 2000, 19(13):3235-3249.

8. Holm A, Tejle K, Magnusson KE, Descoteaux A, Rasmusson B: Leishmania donovani lipophosphoglycan causes periphagosomal actin accumulation: correlation with impaired translocation of PKCalpha and defective phagosome maturation. Cell Microbiol 2001, 3(7):439-447.

9. Sturgill-Koszycki S, Schaible UE, Russell DG: Mycobacterium -containing phagosomes are accessible to early endosomes and reflect a transitional state in normal phagosome biogenesis. Embo J 1996, 15(24):6960-6968.

10. Malik ZA, Iyer SS, Kusner DJ: Mycobacterium tuberculosis phagosomes exhibit altered calmodulin-dependent signal transduction: contribution to inhibition of phagosome-lysosome fusion and intracellular survival in human macrophages. J Immunol 2001, 166(5):3392-3401.

11. Li Y, Miltner E, Wu M, Petrofsky M, Bermudez LE: A Mycobacterium avium PPE gene is associated with the ability of the bacterium to grow in macrophages and virulence in mice. Cell Microbiol 2005, 7(4):539-548.

12. Dheenadhayalan V, Delogu G, Sanguinetti M, Fadda G, Brennan MJ: Variable expression patterns of Mycobacterium tuberculosis PE_PGRS genes: evidence that PE_PGRS16 and PE_PGRS26 are inversely regulated in vivo. J Bacteriol 2006, 188(10):3721-3725.

13. Brennan MJ, Delogu G, Chen Y, Bardarov S, Kriakov J, Alavi M, Jacobs WR Jr: Evidence that mycobacterial PE_PGRS proteins are cell surface constituents that influence interactions with other cells. Infect Immun 2001, 69(12):7326-7333.

14. Delogu G, Pusceddu C, Bua A, Fadda G, Brennan MJ, Zanetti S: Rv1818cencoded PE_PGRS protein of Mycobacterium tuberculosis is surface exposed and influences bacterial cell structure. Mol Microbiol 2004, 52(3):725-733

15. MacGurn JA, Raghavan S, Stanley SA, Cox JS: A non-RD1 gene cluster is required for Snm secretion in Mycobacterium tuberculosis. Mol Microbiol 2005, 57(6):1653-1663.

16. Gagnon E, Duclos S, Rondeau C, Chevet E, Cameron PH, Steele-Mortimer O, Paiement J, Bergeron JJ, Desjardins M: Endoplasmic reticulum-mediated phagocytosis is a mechanism of entry into macrophages. Cell 2002, 110(1):119-131.

17. Wagner D, Maser J, Lai B, Cai Z, Barry CE, Honer Zu, Bentrup K, Russell DG, Bermudez LE: Elemental analysis of Mycobacterium avium -, Mycobacterium tuberculosis-, and Mycobacterium smegmatis-containing phagosomes indicates pathogen-induced microenvironments within the host cell's endosomal system. J Immunol 2005, 174(3):1491-1500.

18. Shrive AK, Tharia HA, Strong P, Kishore U, Burns I, Rizkallah PJ, Reid KB, Greenhough TJ: High-resolution structural insights into ligand binding and immune cell recognition by human lung surfactant protein D. J Mol Biol 2003, 331(2):509-523.

19. Ramakrishnan L, Federspiel NA, Falkow S: Granuloma-specific expression of Mycobacterium virulence proteins from the glycine-rich PE-PGRS family. Science 2000, 288(5470):1436-1439.

20. Sampson SL, Lukey P, Warren RM, van Helden PD, Richardson M, Everett MJ: Expression, characterization and subcellular localization of the Mycobacterium tuberculosis PPE gene Rv1917c. Tuberculosis (Edinb) 2001, 81(5-6):305-317.

21. Camacho LR, Ensergueix D, Perez E, Gicquel B, Guilhot C: Identification of a virulence gene cluster of Mycobacterium tuberculosis by signaturetagged transposon mutagenesis. Mol Microbiol 1999, 34(2):257-267.
22. Vergne I, Chua J, Singh SB, Deretic V: Cell biology of Mycobacterium tuberculosis phagosome. Annu Rev Cell Dev Biol 2004, 20:367-394.

23. Malik ZA, Denning GM, Kusner DJ: Inhibition of $\mathrm{Ca}(2+)$ signaling by Mycobacterium tuberculosis is associated with reduced phagosomelysosome fusion and increased survival within human macrophages. J Exp Med 2000, 191(2):287-302.

24. Malik ZA, Thompson CR, Hashimi S, Porter B, lyer SS, Kusner DJ: Cutting edge: Mycobacterium tuberculosis blocks $\mathrm{Ca} 2+$ signaling and phagosome maturation in human macrophages via specific inhibition of sphingosine kinase. J Immunol 2003, 170(6):2811-2815.

25. Clemens DL, Horwitz MA: Characterization of the Mycobacterium tuberculosis phagosome and evidence that phagosomal maturation is inhibited. J Exp Med 1995, 181(1):257-270

26. Fratti RA, Backer JM, Gruenberg J, Corvera S, Deretic V: Role of phosphatidylinositol 3-kinase and Rab5 effectors in phagosomal biogenesis and mycobacterial phagosome maturation arrest. J Cell Biol 2001, 154(3):631-644

27. Schlesinger LS: Macrophage phagocytosis of virulent but not attenuated strains of Mycobacterium tuberculosis is mediated by mannose receptors in addition to complement receptors. J Immunol 1993, 150(7):2920-2930.

28. Bermudez LE, Young LS, Enkel H: Interaction of Mycobacterium avium complex with human macrophages: roles of membrane receptors and serum proteins. Infect Immun 1991, 59(5):1697-1702.

29. Roecklein JA, Swartz RP, Yeager H Jr: Nonopsonic uptake of Mycobacterium avium complex by human monocytes and alveolar macrophages. J Lab Clin Med 1992, 119(6):772-781.

30. Ren B, McCrory MA, Pass C, Bullard DC, Ballantyne CM, Xu Y, Briles DE, Szalai AJ: The virulence function of Streptococcus pneumoniae surface protein $A$ involves inhibition of complement activation and impairment of complement receptor-mediated protection. J Immunol 2004, 173(12):7506-7512

31. Barel M, Le Romancer M, Frade R: Activation of the EBV/C3d receptor (CR2, CD21) on human $B$ lymphocyte surface triggers tyrosine phosphorylation of the $95-\mathrm{kDa}$ nucleolin and its interaction with phosphatidylinositol 3 kinase. J Immunol 2001, 166(5):3167-3173.

32. Faure $K$, Leberre $R$, Guery B: [Pseudomonas aeruginosa and Surfactantassociated Proteins A and D]. Med Mal Infect 2006, 36(2):63-71.

33. Crouch EC: Surfactant protein-D and pulmonary host defense. Respir Res 2000, 1(2):93-108.

34. Ferguson JS, Martin JL, Azad AK, McCarthy TR, Kang PB, Voelker DR, Crouch EC, Schlesinger LS: Surfactant protein D increases fusion of Mycobacterium tuberculosis -containing phagosomes with lysosomes in human macrophages. Infect Immun 2006, 74(12):7005-7009.

35. Gaynor CD, McCormack FX, Voelker DR, McGowan SE, Schlesinger LS: Pulmonary surfactant protein A mediates enhanced phagocytosis of Mycobacterium tuberculosis by a direct interaction with human macrophages. J Immunol 1995, 155(11):5343-5351.

36. Lopez JP, Clark E, Shepherd VL: Surfactant protein A enhances Mycobacterium avium ingestion but not killing by rat macrophages. $J$ Leukoc Biol 2003, 74(4):523-530.

37. Weikert LF, Lopez JP, Abdolrasulnia R, Chroneos ZC, Shepherd VL: Surfactant protein A enhances mycobacterial killing by rat macrophages through a nitric oxide-dependent pathway. Am J Physiol Lung Cell Mol Physiol 2000, 279(2):L216-223.

38. Hussain S, Zwilling BS, Lafuse WP: Mycobacterium avium infection of mouse macrophages inhibits IFN-gamma Janus kinase-STAT signaling and gene induction by down-regulation of the IFN-gamma receptor. $J$ Immunol 1999, 163(4):2041-2048.

39. Ting LM, Kim AC, Cattamanchi A, Ernst JD: Mycobacterium tuberculosis inhibits IFN-gamma transcriptional responses without inhibiting activation of STAT1. J Immunol 1999, 163(7):3898-3906.

40. Wojciechowski W, DeSanctis J, Skamene E, Radzioch D: Attenuation of MHC class II expression in macrophages infected with Mycobacterium bovis bacillus Calmette-Guerin involves class II transactivator and depends on the Nramp1 gene. J Immunol 1999, 163(5):2688-2696.

41. Flynn JL, Chan J: Immunology of tuberculosis. Annu Rev Immunol 2001, 19:93-129.

42. Garin J, Diez R, Kieffer S, Dermine JF, Duclos S, Gagnon E, Sadoul R, Rondeau C, Desjardins M: The phagosome proteome: insight into phagosome functions. J Cell Biol 2001, 152(1):165-180. 
43. Meresse S, Steele-Mortimer O, Moreno E, Desjardins M, Finlay B, Gorvel JP: Controlling the maturation of pathogen-containing vacuoles: a matter of life and death. Nat Cell Biol 1999, 1(7):E183-188.

44. Wagner D, Maser J, Moric I, Vogt S, Kern WV, Bermudez LE: Elemental analysis of the Mycobacterium avium phagosome in Balb/c mouse macrophages. Biochem Biophys Res Commun 2006, 344(4):1346-1351.

45. Wagner D, Maser J, Moric I, Boechat N, Vogt S, Gicquel B, Lai B, Reyrat JM, Bermudez $\mathrm{L}$ : Changes of the phagosomal elemental concentrations by Mycobacterium tuberculosis Mramp. Microbiology 2005, 151(Pt 1):323-332.

46. McGarvey JA, Wagner D, Bermudez LE: Differential gene expression in mononuclear phagocytes infected with pathogenic and non-pathogenic mycobacteria. Clin Exp Immunol 2004, 136(3):490-500.

47. Vogt S, Maser J, Jacobsen C: Data analysis for $X$-ray fluorescence imagine. Proceedings of the Seventh International Conference on X-ray Microscopy. J Phys IV 2003, 104:617-622.

doi:10.1186/1471-2180-10-100

Cite this article as: Jha et al:: Virulence-related Mycobacterium avium subsp hominissuis MAV_2928 gene is associated with vacuole remodeling in macrophages. BMC Microbiology 2010 10:100.

\section{Submit your next manuscript to BioMed Central} and take full advantage of:

- Convenient online submission

- Thorough peer review

- No space constraints or color figure charges

- Immediate publication on acceptance

- Inclusion in PubMed, CAS, Scopus and Google Scholar

- Research which is freely available for redistribution

Submit your manuscript at www.biomedcentral.com/submit
C Biomed Central 